\title{
PENGEMBANGAN PERANGKAT PEMBELAJARAN TERPADU BERBASIS KEARIFAN LOKAL UNTUK KELAS III SEKOLAH DASAR DI KABUPATEN MADIUN
}

\author{
Dewi Tryanasari* \\ Elly's Mersina Mursidik* \\ Edy Riyanto*
}

\begin{abstract}
This research is attempted to: (1) describe the steps of the development of local-wisdom-based integrated teaching media; (2) describe the quality of the local-wisdom-based teaching media; (3) describe the implementation of local-wisdom-based teaching media; and (4) describe the impacts of the implementation of local-wisdombased teaching media. The method of the research is Dick and Carey's model of Research and Development, which frames the development of teaching instruments. The objects of the research are the developed teaching instruments, and the subjects are 10 students of Balerejo II and 30 students of Balerejo IV. The data are analyzed descriptively by using observation record for the teaching events, and appraisal technique for the teaching instruments. The results of the analysis show that: (1) the teaching instruments can be welldeveloped being measured by the Dick and Carey's model, which are scored as: 4.22 for Lesson Plan, 4.5 for Media, 4.14 for Teacher's Guide, 4.26 for Book, and 3.96 Student Work Sheets; (2) the quality of the local-wisdom media is good; (3) the implementation of the model is good, by $89.75 \%$ of the application of lesson plan in the fisrt meeting and $91.01 \%$ in the second meeting. Students' response is good, by 40.6 (agree) and 41.2 (very much agree). Teacher's activities are good in response to the suggested activities of the lesson plan. Students' activities are good with $99.41 \%$ of the activities are relevant to lesson plan, and the average achievement raise significantly. (4) Supporting factors cope with students' experience in learning amusingly without disturbing contact to their mates. Some disadvantagous factors can be resolved by teacher's improvisations.
\end{abstract}

Key words: Teaching Media Development, Integrated Teaching and Learning

\begin{abstract}
Abstrak
Penelitian ini bertujuan untuk: (1) mendeskripsikan pengembangan media pembelajaran terpadu berbasis kearifan lokal; (2) mendeskripsikan kualitas media kearifan lokal pada pembelajaran
\end{abstract}

* Dewi Tryanasari adalah Dosen Prodi PGSD FIP IKIP PGRI MADIUN

* Elly's Mersina Mursidik adalah Dosen Prodi PGSD FIP IKIP PGRI MADIUN

* Edy Riyanto adalah Dosen Prodi PGSD FIP IKIP PGRI MADIUN 
terpadu; (3) mendeskripsikan implementasi kearifan lokal sebagai media pembelajaran terpadu; dan (4) mendeskripsikan faktor penghambat dan pendukung pembelajaran terpadu menggunakan media kearifan lokal. Prosedur penelitian melalui dua tahap, yaitu pengembangan perangkat pembelajaran dan uji coba perangkat. Objek penelitian adalah perangkat pembelajaran yang dikembangkan, sedangkan subjek uji coba perangkat pembelajaran adalah 10 orang siswa kelas III SDN Balerejo 2 dan 30 orang siswa kelas III SDN Balerejo 4. Perangkat pembelajaran yang dikembangkan mengacu pada model Dick and Carey. Data hasil penelitian dianalisis secara deskriptif kualitatif. Perangkat pembelajaran yang dikembangkan adalah rencana pelaksanaan pembelajaran, media yang tertuang dalam buku pegangan guru, buku ajar siswa, lembar kegiatan siswa, dan tes hasil belajar. Untuk melihat kualitas perangkat serta implementasinya digunakan lembar keterlaksanaan RPP, lembar responsiswa, lembar aktivitas guru, dan lembar aktivitas siswa, sedangkan untuk melihat faktor penghambat dan pendukung peneliti bertindak sebagai instrumen penelitian. Hasil penelitian menunjukkan bahwa: (1) proses pengembangan sesuai dengan model Dick and Carey dan menghasilkan perangkat pembelajaran yang ditinjau dari isi, format, dan bahasa dinyatakan baik terlihat dari nilai rata-rata validitas isi dan konstruk masing-masing perangkat diantaranya RPP mencapai 4,22; media 4,5; BPG 4,14; BAS 4,26; LKS 3,96; (2) kualitas kearifan lokal sebagai media dalam pembelajaran terpadu baik; (3) implementasi penggunaan perangkat ditinjau dari keterlaksanaan RPP baik dengan rata-rata persentase sebesar $89,75 \%$ pada pertemuan 1 dan $91,01 \%$ pada pertemuan 2, respons siswa positif dengan rata-rata persentase 40,6 (setuju) dan 41,2 (sangat setuju), aktivitas guru sangat baik dimana aktivitas relevan semuanya muncul, aktivitas siswa sangat baik dengan persentase mencapai 99,41\% relevan, dan hasil belajar siswa mengalami kenaikan yang signifikan; dan (4) faktor penghambat bisa diatasi dengan improvisasi, sedangkan faktor pendukung yang ditemukan adalah pengalaman siswa bermain dengan alat permainan tanpa berinteraksi dengan teman menjadikan pembelajaran sangat menarik.

Kata Kunci: Pengembangan Media, Pembelajaran Terpadu

\section{A. PENDAhuluan}

Perbedaan karakteristik siswa tentunya mempengaruhi cara beradaptasi individu terhadap lingkungannya, sama dengan yang dihadapi oleh anak selaku individu. Hal ini sejalan dengan pendapat Piaget (1950) bahwa setiap anak memiliki cara tersendiri dalam menginterpretasikan dan beradaptasi dengan lingkungannya. Menurutnya, setiap anak memiliki struktur kognitif yang disebut schemata, yaitu sistem konsep yang ada dalam pikiran sebagai hasil pemahaman terhadap objek yang ada dalam lingkungannya. Pemahaman tentang objek tersebut berlangsung melalui proses asimilasi yaitu, proses menghubungkan objek 
dengan konsep yang sudah ada dalam pikiran dan proses akomodasi yaitu, proses memanfaatkan konsep-konsep dalam pikiran untuk menafsirkan objek. Kedua proses tersebut jika berlangsung terus- menerus akan membuat pengetahuan lama dan pengetahuan baru menjadi seimbang. Dengan cara seperti itu, secara bertahap anak dapat membangun pengetahuan melalui interaksi dengan lingkungannya.

Anak usia sekolah dasar berada pada tahapan operasi konkret. Pada rentang usia sekolah dasar tersebut anak mulai menunjukkan perilaku belajar: (1) mulai memandang dunia secara objektif, bergeser dari satu aspek situasi ke aspek lain secara reflektif dan memandang unsur-unsur secara serentak; (2) mulai berpikir secara operasional; (3) mempergunakan cara berpikir operasional untuk mengklasifikasikan benda-benda; (4) membentuk dan mempergunakan keterhubungan aturan-aturan; prinsip ilmiah sederhana, dan mempergunakan hubungan sebab akibat; dan (5) memahami konsep substansi, volume zat cair, panjang, lebar, luas, dan berat. Memerhatikan tahapan perkembangan berpikir tersebut, kecenderungan belajar anak usia sekolah dasar memiliki tiga ciri, yaitu konkret, integratif, dan hierarkis. Konkret mengandung makna proses belajar beranjak dari hal-hal yang konkret yakni yang dapat dilihat, didengar, dibaui, diraba, dan diotak-atik dengan titik penekanan pada pemanfaatan lingkungan sebagai sumber belajar. Pemanfaatan lingkungan akan menghasilkan proses dan hasil belajar yang lebih bermakna dan bernilai sebab siswa dihadapkan dengan peristiwa dan keadaan yang sebenarnya, keadaan yang alami sehingga lebih nyata, faktual, bermakna, dan kebenarannya lebih dapat dipertanggungjawabkan. Integratif mengandung makna bahwa pada tahap usia sekolah dasar anak memandang sesuatu yang dipelajari sebagai suatu keutuhan, mereka belum mampu memilah-milah konsep dari berbagai disiplin ilmu. Hal ini melukiskan cara berpikir anak yang deduktif yakni dari hal umum ke bagian demi bagian. Hierarkis mengandung makna bahwa pada tahapan usia sekolah dasar, cara anak belajar berkembang secara bertahap mulai dari hal-hal yang sederhana ke hal-hal yang lebih kompleks.

Bertitik tolak pada penjelasan di atas, perlu adanya rancangan pembelajaran yang sesuai dengan tahapan perkembangan anak SD. Rancangan pembelajaran yang dimaksud adalah rancangan pembelajaran yang mampu mewadahi keholistikan dan kekonkretan belajar anak. Pembelajaran terpadu merupakan suatu aplikasi strategi pembelajaran berdasarkan pendekatan kurikulum terpadu yang secara sengaja mengaitkan beberapa aspek baik dalam intra mata pelajaran maupun antar mata pelajaran. Dengan pemaduan itu anak akan memperoleh pengetahuan secara utuh sehingga pembelajaran menjadi bermakna bagi siswa. Bermakna di sini berarti bahwa siswa akan memahami apa yang dipelajarinya melalui pengalaman langsung dan nyata yang menghubungkan intra konsep mata pelajaran maupun antarkonsep mata pelajaran (Sukayati, 2004: 2). Pembelajaran terpadu sangat memperhatikan kebutuhan anak sesuai dengan perkembangannya yang holistik dengan melibatkan secara aktif dalam proses pembelajaran baik fisik maupun emosionalnya. Untuk itu aktivitas yang diberikan meliputi aktif mencari, menggali, dan menemukan konsep serta prinsip keilmuan yang holistik, bermakna, dan autentik sehingga siswa dapat menerapkan perolehan belajar untuk memecahkan masalah-masalah yang nyata di dalam kehidupan sehari-hari. 
Hasil observasi awal di lapangan menunjukkan bahwa pembelajaran di SD kelas rendah di wilayah Kabupaten Madiun, belum menggunakan pembelajaran terpadu. Hal ini terlihat dari jadwal pelajaran yang dibuat oleh sekolah. Pada pembelajaran terpadu di kelas rendah, seharusnya jadwal dibuat per tema dengan ketentuan jam sesuai program yang dibuat oleh guru kelas dan tidak nampak pemisahan antar mata pelajaran. Namun kenyataannya jadwal pelajaran kelas rendah di SD wilayah Kabupaten Madiun masih nampak pemisahan pada mata pelajaran, misalnya jam pertama dan kedua Bahasa Indonesia, jam ketiga dan keempat olahraga, serta jam kelima dan keenam IPA. Selain penjadwalan, bukti lain tidak terlaksananya pembelajaran terpadu kelas rendah di SD wilayah Kabupaten Madiun adalah model rencana pembelajaran yang dibuat oleh guru masih terpisah (mencantumkan nama matapelajaran), begitu juga dengan skenario pembelajaran yang merupakan bagian penting dari Rencana Pelaksanaan Pembelajaran. Akibatnya proses pembelajaran di kelas pun masih menggunakan model pembelajaran nonterpadu yang memisahkan antar mata pelajaran sehingga keholistikan cara pandang dan cara belajar anak tidak terwadahi. Masalah lain yang teramati di lapangan adalah guru SD di wilayah Kabupaten Madiun belum memanfaatkan kondisi sosial budaya yang menjadi latar belakang lingkungan sekolah untuk pembelajaran sehingga pembelajaran pun terlepas dari konteks dunia nyata yang dihadapi oleh siswa sehari-hari. Tentunya hal ini membuat kekonkretan belajar anak juga tidak terwadahi. Akibatnya materi yang seharusnya lebih mudah dikuasai menjadi sulit dikuasai oleh siswa.

Ketidakterlaksanaan pembelajaran terpadu di kelas rendah tersebut berakar dari kebingungan guru dalam menafsirkan pembelajaran terpadu tipe Webbed yang dijabarkan dalam jaring tematis dalam KTSP. Selain itu dalam mengembangkan perangkat pembelajaran, guru di satu sekolah berpatok pada silabus contoh terbitan BSNP tanpa melakukan penyortiran konteks. Padahal silabus terbitan BSNP tersebut mengambil latar daerah Jawa Barat dan penjabaran indikatornya bersifat sangat umum. Akibatnya jika Silabus tersebut dijadikan acuan oleh guru di Kabupaten Madiun menjadi tidak sesuai dengan kondisi nyata yang dialami oleh anak sehari-sehari. Permasalahan tersebut, bisa diatasi dengan memberikan alternatif contoh nyata pengembangan perangkat pembelajaran terpadu serta bagaimana mengajar secara terpadu dengan mempertimbangkan kearifan lokal di Kabupaten Madiun atau memberikan pelatihan kepada guru SD untuk memanfaatkan kearifan lokal dalam mengembangkan perangkat pembelajaran terpadu. Pelatihan guru tidak dipilih karena program ini sudah banyak dilakukan melalui seminar dan lokakarya dari dinas terkait. Pelatihan terhadap guru dinilai tidak efektif untuk mengatasi permasalahan karena memerlukan waktu yang cukup lama serta monitoring yang intens sehingga manfaat nyatanya akan dirasakan setelah jangka waktu yang lama.

Alternatif pertama dipilih sebab hasil pengembangan perangkat pembelajaran terpadu bisa langsung digunakan dalam konteks pembelajaran nyata. Produk akhir dari penelitian ini diharapkan akan memberikan contoh konkret pada guru untuk bisa mengembangkan perangkat pembelajaran terpadu bagi pokok-pokok bahasan pembelajaran terpadu yang lain. Penelitian ini menitikberatkan pada pembelajaran terpadu penelitian di atas menitikberatkan pada mata pelajaran IPA dan IPS. Selain itu kedua penelitian di atas tidak mempertimbangkan kearifan lokal sebagai latar penelitian sedangkan penelitian 
yang akan dilakukan ini justru menjadikan kearifan lokal sebagai bahan pertimbangan utama dalam mengembangkan perangkat pembelajaran. Dengan demikian bisa dikatakan bahwa penelitian ini merupakan penelitian yang orisinal.

\section{B. KAJIAN PUSTAKA}

\section{Karakteristik Belajar Anak Sekolah Dasar}

Anak di kelas awal SD adalah anak yang berada pada rentangan usia dini dengan masa perkembangan yang pendek tetapi merupakan masa yang sangat penting bagi kehidupannya. Oleh karena itu, pada masa ini seluruh potensi yang dimiliki anak perlu didorong sehingga akan berkembang secara optimal. Karakteristik perkembangan anak pada kelas satu, dua dan tiga SD biasanya pertumbuhan fisiknya telah mencapai kematangan, mereka telah mampu mengontrol tubuh dan keseimbangannya. Mereka telah dapat melompat dengan kaki secara bergantian, dapat mengendarai sepeda roda dua, dapat menangkap bola dan telah berkembang koordinasi tangan dan mata untuk dapat memegang pensil maupun memegang gunting. Selain itu, perkembangan anak dari sisi sosial, terutama anak yang berada pada usia kelas awal SD antara lain mereka telah dapat menunjukkan keakuannya tentang jenis kelaminnya, telah mulai berkompetisi dengan teman sebaya, mempunyai sahabat, telah mampu berbagi, dan mandiri. Dari sisi emosi anak telah dapat mengekspresikan reaksi terhadap orang lain, telah dapat mengontrol emosi, sudah mampu berpisah dengan orang tua dan telah mulai belajar tentang konsep nilai misalnya benar dan salah. Untuk perkembangan kecerdasannya anak usia kelas awal SD ditunjukkan dengan kemampuannya dalam melakukan seriasi, mengelompokkan obyek, berminat terhadap angka dan tulisan, meningkatnya perbendaharaan kata, senang berbicara, memahami sebab akibat dan berkembangnya pemahaman terhadap ruang dan waktu.

Memperhatikan tahapan perkembangan berpikir tersebut, kecenderungan belajar anak usia sekolah dasar memiliki tiga ciri, yaitu: (1) konkret, mengandung makna proses belajar beranjak dari hal-hal yang konkrit yakni yang dapat dilihat, didengar, dibaui, diraba, dan diotak atik, dengan titik penekanan pada pemanfaatan lingkungan sebagai sumber belajar. Pemanfaatan lingkungan akan menghasilkan proses dan hasil belajar yang lebih bermakna dan bernilai, sebab siswa dihadapkan dengan peristiwa dan keadaan yang sebenarnya, keadaan yang alami, sehingga lebih nyata, lebih faktual, lebih bermakna, dan kebenarannya lebih dapat dipertanggungjawabkan; (2) integratif, pada tahap usia sekolah dasar anak memandang sesuatu yang dipelajari sebagai suatu keutuhan, mereka belum mampu memilah-milah konsep dari berbagai disiplin ilmu, hal ini melukiskan cara berpikir anak yang deduktif yakni dari hal umum ke bagian demi bagian; dan (3) hierarkis, pada tahapan usia sekolah dasar, cara anak belajar berkembang secara bertahap mulai dari hal-hal yang sederhana ke hal-hal yang lebih kompleks. Sehubungan dengan hal tersebut, maka perlu diperhatikan mengenai urutan logis, keterkaitan antar materi, dan cakupan keluasan serta kedalaman materi.

\section{Pembelajaran Terpadu}

a. Konsep Pembelajaran Terpadu

Terdapat tiga kemungkinan variasi pembelajaran terpadu yang berkenaan dengan pendidikan yang dilaksanakan dalam suasana pendidikan progresif yaitu kurikulum terpadu (integrated curriculum), hari terpadu (integrated day), dan 
pembelajaran terpadu (integrated learning). Kurikulum terpadu adalah kegiatan menata keterpaduan berbagai materi mata pelajaran melalui suatu tema lintas bidang membentuk suatu keseluruhan yang bermakna sehingga batas antara berbagai bidang studi tidaklah ketat atau boleh dikatakan tidak ada. Hari terpadu berupa perancangan kegiatan siswa dari sesuatu kelas pada hari tertentu untuk mempelajari atau mengerjakan berbagai kegiatan sesuai dengan minat mereka. Sementara itu, pembelajaran terpadu menunjuk pada kegiatan belajar yang terorganisasikan secara lebih terstruktur yang bertolak pada tema-tema tertentu sebagai titik pusatnya (center core/center of interest). Prabowo (2000: 2) menyatakan, pembelajaran terpadu adalah suatu proses pembelajaran dengan melibatkan/mengaitkan berbagai bidang studi. Pendekatan belajar mengajar seperti ini diharapkan akan dapat memberikan pengalaman yang bermakna kepada anak didik kita. Dalam pembelajaran terpadu diharapkan anak akan memperoleh pemahaman terhadap konsep-konsep yang mereka pelajari dengan melalui pengalaman langsung dan menghubungkannya dengan konsep lain yang sudah mereka pahami. Pembelajaran terpadu merupakan pendekatan belajar mengajar yang memperhatikan dan menyesuaikan dengan tingkat perkembangan anak didik (developmentally appropriate practical). Pendekatan yang berangkat dari teori pembelajaran yang menolak drill-system sebagai dasar pembentukan pengetahuan dan struktur intelektual anak. Integrated atau terpadu bisa mengacu pada integrated curricula (kurikulum terpadu) atau integrated approach (pendekatan terpadu) atau integrated learning (pembelajaran). Pada pelaksanaannya istilah kurikulum terpadu atau pembelajaran terpadu atau pendekatan terpadu dapat dipertukarkan, kurikulum terpadu adalah suatu bentuk cara atau pendekatan untuk mengorganisasikan kurikulum dengan cara menghapus semua garis batas mata pelajaran yang terpisah-pisah, sedangkan pembelajaran terpadu merupakan metode pengorganisasian pembelajaran yang menggunakan beberapa bidang mata pelajaran yang sesuai.

Pembelajaran dengan menggunakan pendekatan terpadu ini diharapkan akan dapat memperbaiki kualitas pendidikan dasar, terutama untuk mencegah gejala penjejalan kurikulum dalam proses pembelajaran di sekolah. Dampak negatif dari penjejalan kurikulum akan berakibat buruk terhadap perkembangan anak. Hal tersebut terlihat dengan dituntutnya anak untuk mengerjakan berbagai tugas yang melebihi kapasitas dan kebutuhan mereka. Mereka kurang mendapat kesempatan untuk belajar, untuk membaca dan sebagainya. Di samping itu mereka akan kehilangan pengalaman pembelajaran alamiah langsung, pengalaman sensorik dari dunia mereka yang akan membentuk dasar kemampuan pembelajaran abstrak (Prabowo, 2000: 3). Pembelajaran terpadu sebagai suatu proses mempunyai beberapa ciri diantaranya, berpusat pada anak (student centered), proses pembelajaran mengutamakan pemberian pengalaman langsung, serta pemisahan antar bidang studi tidak terlihat jelas. Di samping itu pembelajaran terpadu menyajikan konsep dari berbagai bidang studi dalam satu proses pembelajaran. Kecuali mempunyai sifat luwes, pembelajaran terpadu juga memberikan hasil yang dapat berkembang sesuai dengan minat dan kebutuhan anak. Pembelajaran terpadu memiliki kelebihan, yaitu: (1) pengalaman dan kegiatan belajar anak relevan dengan tingkat perkembangannya; (2) kegiatan yang dipilih sesuai dengan minat dan kebutuhan anak; (3) kegiatan belajar bermakna bagi anak, sehingga hasilnya dapat bertahan lama; (4) keterampilan berpikir anak 
berkembang dalam proses pembelajaran terpadu; (5) kegiatan belajar mengajar bersifat pragmatis sesuai dengan lingkungan anak; dan (6) keterampilan sosial anak berkembang dalam proses pembelajaran terpadu. Keterampilan sosial ini antara lain adalah: kerja sama, komunikasi, dan mau mendengarkan pendapat orang lain (Depdikbud, 1996).

Salah satu keterbatasan yang menonjol dari pembelajaran terpadu adalah pada faktor evaluasi. Pembelajaran terpadu menuntut diadakannya evaluasi tidak hanya pada produk, tetapi juga pada proses. Evaluasi pembelajaran terpadu tidak hanya berorientasi pada dampak instruksional dari proses pembelajaran, tetapi juga pada proses dampak pengiring dari proses pembelajaran tersebut. Dengan demikian pembelajaran terpadu menuntut adanya teknik evaluasi yang banyak ragamnya. Oleh karenanya tugas guru menjadi lebih banyak (Prabowo, 2000:4). Lebih lanjut Prabowo (2000:5) menyatakan bahwa dari kalangan pendidik terdapat berbagai pendapat yang intinya menyatakan bahwa penerapan pendekatan pembelajaran terpadu akan banyak menimbulkan masalah dan tugas guru menjadi semakin membengkak. Masalah yang menonjol adalah tentang penyesuaian pola penerapan dan hasil pembelajaran terpadu dikaitkan dengan kurikulum yang sedang berlaku. Dalam mengatasi masalah ini, pada tahap awal dapat dilakukan dengan memeriksa isi kurikulum dalam satu catur wulan secara fleksibel. Artinya materi dalam satu catur wulan tersebut dapat diatur urutan pembelajarannya, asal cakupannya tetap tercapai. Berangkat dari pokok pemikiran tersebut di atas, maka sebelum merancang pembelajaran terpadu, hendaknya guru mengumpulkan dan menyusun seluruh pokok bahasan dari semua bidang studi dalam satu catur wulan, kemudian dilanjutkan dengan proses perancangan pembelajaran terpadu.

b. Jenis Pembelajaran Terpadu

Prabowo (2000: 3) menyatakan bahwa pembelajaran terpadu sebagai suatu proses mempunyai beberapa ciri-ciri, yaitu: (1) berpusat pada siswa (student centered); (2) proses pembelajaran mengutamakan pemberian pengalaman langsung; dan (3) pemisahan antar bidang studi tidak terlihat jelas. Dari beberapa ciri-ciri pembelajaran terpadu di atas, menunjukkan bahwa model pembelajaran terpadu adalah sejalan dengan beberapa aliran pendidikan modern yaitu termasuk dalam aliran pendidikan progresivisme. Aliran pendidikan progresivisme memandang pendidikan yang mengutamakan penyelenggaraan pendidikan di sekolah berpusat pada anak (child-centered), sebagai reaksi terhadap pelaksanaan pendidikan yang masih berpusat pada guru dan pada bahan ajar. Tujuan utama sekolah adalah untuk meningkatkan kecerdasan praktis, serta untuk membuat anak lebih efektif dalam memecahkan berbagai problem yang disajikan dalam konteks pengalaman (experience) pada umumnya (O'neill, 1981). Tujuan pendidikan aliran progresivisme adalah melatih anak agar kelak dapat bekerja, bekerja secara sistematis, mencintai kerja, dan bekerja dengan otak dan hati. Untuk mencapai tujuan tersebut, pendidikan seharusnya dapat mengembangkan sepenuhnya bakat dan minat setiap anak. Kurikulum pendidikan progresif adalah kurikulum yang mengakomodasi pengalaman-pengalaman (atau kegiatan) belajar yang diminati oleh setiap siswa (experience curriculum).

Adapun model-model pembelajaran terpadu sebagaimana yang dikemukakan oleh Fogarty (1991: 61-65) yaitu sebanyak sepuluh model 
pembelajaran terpadu. Kesepuluh model pembelajaran terpadu tersebut adalah: (1) the fragmented model (Model Fragmen); (2) the connected model (Model Terhubung); (3) the nested model (Model Tersarang); (4) the sequenced model (Model Terurut); (5) the shared model (Model Terbagi); (6) the webbed model (Model Jaring Laba-Laba); (7) the threaded model (Model Pasang Benang); (8) the integrated model (Model Integrasi); (9) the immersed model (Model Terbenam); dan (10) the networked model (Model Jaringan). Dari kesepuluh model pembelajaran terpadu di atas dipilih tiga model pembelajaran yang dipandang layak dan sesuai untuk dapat dikembangkan dan mudah dilaksanakan di pendidikan dasar (Prabowo, 2000: 7). Ketiga model pembelajaran terpadu yang dimaksud adalah model terhubung (connected), model jaring laba-laba (webbed), model keterpaduan (integrated).

\section{c. Pelaksanaan Pembelajaran Terpadu di Kelas Rendah}

Peserta didik sekolah dasar kelas satu, dua, dan tiga berada pada rentangan usia dini. Pada usia tersebut seluruh aspek perkembangan kecerdasan seperti IQ, EQ, dan SQ tumbuh dan berkembang sangat luar biasa. Pada umumnya mereka masih melihat segala sesuatu sebagai satu keutuhan (berpikir holistik) dan memahami hubungan antara konsep secara sederhana. Proses pembelajaran masih bergantung kepada objek-objek konkret dan pengalaman yang dialami secara langsung. Pada kurikulum 1994 pelaksanaan kegiatan pembelajaran di SD kelas I s.d. III untuk setiap mata pelajaran dilakukan secara terpisah. Dalam pelaksanaan kegiatannya dilakukan secara murni mata pelajaran yaitu hanya mempelajari materi yang berhubungan dengan mata pelajaran itu. Sesuai dengan tahapan perkembangan anak yang masih melihat segala sesuatu sebagai suatu keutuhan (berpikir holistik), pembelajaran yang menyajikan mata pelajaran secara terpisah akan menyebabkan kurang mengembangkan anak untuk berpikir holistik dan membuat kesulitan bagi peserta didik.

Selain itu, dengan pelaksanaan pembelajaran yang terpisah, muncul permasalahan pada kelas rendah (I s.d. III), adalah tingginya angka mengulang kelas dan putus sekolah. Angka mengulang kelas dan angka putus sekolah peserta didik kelas I SD jauh lebih tinggi dibandingkan dengan kelas yang lain. Data tahun 1999/2000 memperlihatkan bahwa angka mengulang kelas satu sebesar $11,6 \%$ sementara pada kelas dua 7,51\%, kelas tiga 6,13\%, kelas empat 4,64\%, kelas lima $3,1 \%$, dan kelas enam $0,37 \%$. Pada tahun yang sama angka putus sekolah kelas satu sebesar 4,22\%, masih jauh lebih tinggi jika dibandingkan dengan kelas dua $0,83 \%$, kelas tiga $2,27 \%$, kelas empat $2,71 \%$, kelas lima $3,79 \%$, dan kelas enam 1,78\%. Angka nasional tersebut semakin memprihatinkan jika dilihat dari data di masing-masing propinsi terutama yang hanya memiliki sedikit taman kanak-kanak. Pada saat ini hanya sedikit peserta didik kelas satu sekolah dasar yang mengikuti pendidikan prasekolah sebelumnya. Tahun 1999/2000 tercatat hanya $12,61 \%$ atau 1.583 .467 peserta didik usia 4-6 tahun yang masuk taman Kanak-kanak, dan kurang dari $5 \%$ peserta didik berada pada pendidikan prasekolah lain. Permasalahan tersebut menunjukkan bahwa kesiapan bersekolah sebagian besar peserta didik kelas awal sekolah dasar di Indonesia cukup rendah. Atas dasar pemikiran di atas dan dalam rangka implementasi Standar Isi yang termuat dalam Standar Nasional Pendidikan, maka pembelajaran pada kelas awal sekolah dasar yakni kelas satu, dua, dan tiga lebih sesuai jika dikelola dalam 
pembelajaran terpadu melalui pendekatan pembelajaran tematik. Untuk memberikan gambaran tentang pembelajaran tematik yang dapat menjadi acuan dan contoh konkret, disiapkan model pelaksanaan pembelajaran tematik SD/MI kelas I hingga kelas III.

Berdasarkan uraian tersebut, disimpulkan pelaksanaan pembelajaran terpadu di SD dilakukan dengan pembelajaran tematik. Dalam pembelajaran tematik, keterpaduan dilakukan dengan mewadahi kompetensi dasar yang harus dikuasai siswa ke dalam tema-tema tertentu. Jika dibandingkan pembelajaran tematik sebenarnya sama dengan pembelajaran terpadu model Webbed. Oleh karena itu pembelajaran terpadu model Webbed ini diilih untuk dilaksanakan dalam pembelajaran di SD kelas rendah. Hal ini sesuai dengan pendapat Prabowo (2000:7) yang menyatakan bahwa model Webbed (jaring laba-laba) sesuai untuk digunakan dalam pembelajaran di SD.

\section{Rencana Pelaksanaan Pembelajaran}

Rencana pelaksanaan pembelajaran adalah keseluruhan proses analisis kebutuhan dan tujuan belajar serta pengembangan sistem penyampaiannya untuk memenuhi kebutuhan dan mencapai tujuan belajar. Rencana pelaksanaan pembelajaran meliputi pengembangan paket pembelajaran, kegiatan pembelajaran, uji coba dan revisi paket pembelajaran, dan kegiatan evaluasi program dan hasil belajar (Ghafur, 2007: 7). Ada beberapa prinsip yang harus dipegang ketika merencanakan pembelajaran. Brigs menyatakan bahwa desain pembelajaran dikembangkan atas dasar pengajaran dapat didisain secara lebih sistematis berbeda dengan cara-cara tradisional (Ghafur, 2007: 9). Bertitik tolak dari hal itu, komponen-komponen pembelajaran harus relevan, konsisten, dan selaras. Pada dasarnya pengembangan pembelajaran harus didasarkan pada asumsi-asumsi, yaitu: (1) hasil pembelajaran dapat dirumuskan secara operasional sehingga dapat diamati dan diukur; (2) tercapainya tujuan pembelajaran dapat diukur dengan menggunakan instrumen yang disebut acuan patokan (Criterion Referenced Test) yaitu tes yang didasarkan atas kriteria (dalam hal ini adalah tujuan pembelajaran khusus) sehingga dapat dibedakan antara siswa mencapai hasil yang diharapkan dengan siswa tidak dapat mencapai hasil yang diharapkan; dan (3) untuk menjamin efektivitas proses pembelajaran paket pembelajaran yang digunakan harus memenuhi status valid.

Desain pembelajaran pada dasarnya dikembangkan berdasarkan teori sistem. Penerapan teori sistem dalam pengembangan rencana pembelajaran adalah dikembangkannya komponen-komponen pengajaran secara sistematis dan terintegrasi. Komponen-komponen yang terlibat dalam pengajaran antara lain adalah tujuan pembelajaran, materi pembelajaran, metode, alat dan evaluasi. Dalam pembelajaran di Indonesia prinsip-prinsip tersebut dituangkan di Permendiknas Nomor 41 tahun 2007. Permendiknas Nomor 41 tahun 2007 menyatakan bahwa: (1) RPP dijabarkan dari silabus untuk mengarahkan kegiatan belajar peserta didik dalam upaya mencapai KD; (2) Setiap guru pada satuan pendidikan berkewajiban menyusun RPP secara lengkap dan sistematis agar pembelajaran berlangsung secara interaktif, inspiratif, menyenangkan, menantang, memotivasi peserta didik untuk berpartisipasi aktif, serta memberikan ruang yang cukup bagi prakarsa, kreativitas, dan kemandirian sesuai dengan bakat, minat, dan perkembangan fisik serta psikologis peserta didik; (3) RPP disusun untuk setiap 
KD yang dapat dilaksanakan dalam satu kali pertemuan atau lebih. Guru merancang RPP untuk setiap pertemuan yang disesuaikan dengan penjadwalan di satuan pendidikan; dan (4) komponen RPP meliputi identitas matapelajaran, standar kompetensi, kompetensi dasar, indikator pencapaian kompetensi, tujuan pembelajaran, materi ajar, alokasi waktu, metode pembelajaran, kegiatan pembelajaran, penilaian hasil belajar, media, dan sumber belajar. Seorang guru dalam menyusun RPP harus memperhatikan prinsip-prinsip penyusunan RPP, yaitu: (1) memperhatikan perbedaan individu peserta didik; (2) mendorong partisipasi aktif peserta didik; (3) mengembangkan budaya membaca dan menulis; (4) memberikan umpan balik dan tindak lanjut; (5) keterkaitan dan keterpaduan; dan (6) menerapkan teknologi informasi dan komunikasi.

\section{Keterlaksanaan Perencanaan Pembelajaran}

Ghafur (2007:14) menyatakan bahwa disain pembelajaran termasuk rencana pembelajaran pada dasarnya digunakan untuk menjamin proses keterlaksanaan pembelajaran di kelas. Oleh karena itu rencana pembelajaran harus memfasilitasi kondisi nyata di kelas. Selain itu keterlaksanaan rencana pembelajaran juga ditentukan oleh siapa yang menggunakan rencana tersebut. Untuk memenuhi kriteria keterlaksanaan rencana pembelajaran, komponenkomponen yang ada dalam rencana pengajaran harus nampak pada proses belajar mengajar itu sendiri. Komponen-komponen dimaksud terutama menyangkut langkah pembelajaran yang meliputi kegiatan awal, akhir, dan inti yang melibatkan ketepatan guru dalam mengelola waktu pembelajaran.

\section{Respons sebagai Salah Satu Kecerdasan Afektif}

Untuk mengetahui pengaruh media yang digunakan cocok dengan kondisi anak di lapangan, tidak bisa hanya diukur melalui subtansi hasil belajar anak. Skor hasil belajar yang tinggi hanya salah satu indikasi dari keberhasilan pengajaran. Hasil belajar menurut Bloom (1976) mencakup prestasi belajar, kecepatan belajar, dan hasil afektif. Andersen (1981) sependapat dengan Bloom bahwa karakteristik manusia meliputi tipikal dari berpikir, berbuat, dan perasaan. Tipikal berpikir berkaitan dengan ranah kognitif, tipikal berbuat berkaitan dengan ranah psikomotor, dan tipikal perasaan berkaitan dengan ranah afektif. Ranah afektif mencakup watak perilaku seperti perasaan, minat, sikap, emosi, atau nilai. Ketiga ranah tersebut merupakan karakteristik manusia sebagai hasil belajar dalam bidang pendidikan. Menurut Anderson (1981), ranah afektif menentukan keberhasilan belajar seseorang. Orang yang tidak memiliki minat pada pelajaran tertentu sulit untuk mencapai keberhasilan belajar secara optimal. Seseorang yang berminat dalam suatu mata pelajaran diharapkan akan mencapai hasil pembelajaran yang optimal.

Oleh karena itu semua pendidik harus mampu membangkitkan minat semua peserta didik untuk mencapai kompetensi yang telah ditentukan. Selain itu ikatan emosional sering diperlukan untuk membangun semangat kebersamaan, semangat persatuan, semangat nasionalisme, rasa sosial, dan sebagainya. Untuk itu semua dalam merancang program pembelajaran, satuan pendidikan harus memperhatikan ranah afektif. Menurut Krathwohl bila ditelusuri hampir semua tujuan kognitif mempunyai komponen afektif (Mubarok, 2008). Dalam pembelajaran sains, misalnya di dalamnya ada 
komponen sikap ilmiah. Sikap ilmiah adalah komponen afektif. Tingkatan ranah afektif menurut taksonomi Krathwohl ada lima, yaitu: receiving (attending), responsding, valuing, organization, dan characterization.

\section{Aktivitas dalam Pembelajaran}

Aktivitas adalah segala kegiatan yang dilakukan oleh individu dalam rangka mencapai tujuan tertentu. Sedangkan pembelajaran adalah proses interaksi peserta didik dengan pendidik dan sumber belajar pada suatu lingkungan belajar (Undang-undang Nomor 20 tahun 2003 tentang Sisdiknas). Dari kedua pengertian tersebut dapat diambil sebuah kesimpulan bahwa aktivitas dalam pembelajaran adalah segala kegiatan yang dilakukan oleh individu dalam proses interaksi peserta didik dan pendidik dan sumber belajar pada suatu lingkungan belajar. Tentunya dalam kegiatan tersebut baik guru maupun siswa mempunyai karakteristik yang berbeda. Untuk itu aktivitas guru dan aktivitas siswa akan dijelaskan lebih lanjut sebagai berikut.

\section{a. Aktivitas Guru}

Aktivitas guru sebagaimana dijelaskan sebelumnya adalah kegiatan yang dilakukan guru dalam pembelajaran. Tentunya kegiatan yang dilakukan guru dalam pembelajaran bukanlah kegiatan yang sembarangan. Aktivitas yang dilakukan oleh guru harus berorientasi pada keberhasilan tujuan pembelajaran. Oleh karena itu guru harus menyesuaikan aktivitasnya dengan rencana pembelajaran yang telah dibuat. Catharina menyatakan adakalanya guru harus melakukan improvisasi dalam aktivitasnya namun sebatas hal itu dilakukan untuk mencapai keefektifan pembelajaran, dibolehkan (Ardi, 2007). Adakalanya karena kondisi tertentu guru melakukan aktivitas yang tidak berorientasi pada keberhasilan pembelajaran maka aktivitas guru ini dianggap sebagai aktivitas yang tidak relevan dengan pembelajaran. Dari uraian tersebut dapat disimpulkan bahwa aktivitas guru dalam pembelajaran ada 2 macam yaitu aktivitas yang relevan dengan pembelajaran dan akktivitas yang tidak relevan dengan pembelajaran. Aktivitas yang relevan dengan pembelajaran terbagi menjadi aktivitas yang sesuai dengan RPP dan aktivitas yang merupakan improvisasi.

\section{b. Aktivitas Siswa}

Diedrich membuat suatu daftar kegiatan siswa yang dapat digolongkan (Ardi, 2007), yakni: (1) visual activities yaitu aktivitas yang mencakup membaca, memperhatikan gambar, demonstrasi, dan percobaan; (2) oral activities yaitu aktivitas yang mencakup kegiatan berbicara seperti merumuskan, bertanya, memberi saran, mengeluarkan pendapat, wawancara, diskusi, dan interupsi; (3) listening activities adalah aktivitas yang terkait dengan kegiatan mendengarkan; (4) writing activities adalah aktivitas yang terkait dengan kegiatan menulis seperti menulis cerita, karangan, laporan, angket, menyalin; (5) drawing activities adalah kegiatan yang terkait dengan menggambar, membuat grafik, peta, dan diagram; dan (6) motor activities ialah kegiatan yang terkait dengan melakukan percobaan, membuat konstruksi, model mereparasi, bermain, berkebun, beternak. Keenam aktivitas tersebut muncul sebagai aktivitas yang relevan dengan pembelajaran jika memang kehadirannya sesuai dengan kegiatan belajar yang harus dilakukan. Misalnya dalam oral aktivities tentunya pertanyaan yang diharapkan muncul adalah pertanyaan yang sesuai dengan konteks pembelajaran. 


\section{Buku Model Pembelajaran}

a. Buku Pegangan Guru

Buku pegangan guru adalah sumber belajar yang berbentuk buku yang dapat langsung digunakan oleh guru dalam menyampaikan pembelajaran kepada siswa. Selain berupa buku yang langsung bisa digunakan oleh guru, buku pegangan guru juga bisa berupa buku yang ditulis oleh guru sendiri yang isinya meliputi pengembangan materi pokok yang ada dalam silabus dan dilengkapi dengan metode pembelajaran kepada siswa. Dalam menyusun buku pegangan guru ada beberapa prinsip yang harus dipenuhi yaitu prinsip relevansi, prinsip konsistensi, dan prinsip kecukupan. Prinsip relevansi berarti keterkaitan antara materi ajar yang ada dalam buku pegangan guru dengan pencapaian kompetensi dasar yang diajarkan. Prinsip konsistensi dimaknai sebagai ajeg. Keajegan sebuah buku pegangan guru ditunjukkan dengan kesesuaian jumlah kompetensi dasar yang harus dikuasai oleh siswa dengan jumlah materi yang dituliskan. Sedangkan prinsip kecukupan mengandung pengertian materi yang diajarkan hendaknya cukup memadai dalam membantu siswa menguasai kompetensi dasar yang diajarkan (Yustisia, 2007: 195).

Buku pegangan guru memberikan kontribusi yang penting dalam proses pembelajaran. Oleh karena itu harus ada standar yang diikuti ketika guru memilih atau menulis sendiri buku pegangan yang hendak digunakannya dalam pembelajaran. Pusat Perbukuan (2003) menyatakan bahwa setiap buku pelajaran diharapkan memenuhi standar-standar tertentu yang ditetapkan berdasarkan kebutuhan siswa dan guru, perkembangan ilmu pengetahuan dan teknologi, serta tuntutan kurikulum. Standar yang dimaksud dalam pedoman penilaian ini meliputi persyaratan, karakteristik, dan kompetensi minimum yang harus terkandung di dalam suatu buku. Standar penilaian dirumuskan dengan melihat tiga aspek utama, yaitu materi, penyajian, dan bahasa/keterbacaan. Aspek isi meliputi kelengkapan , keakuratan , serta kegiatan yang mendukung materi, kemutakhiran, dan pengorganisasian materi. Aspek penyajian atau format meliputi tampilan umum, tata letak, pemilihan huruf, dan variasi dalam cara menyampaikan materi sedangkan aspek bahasa atau keterbacaan meliputi kejelasan maksud kalimat, kesesuaian bahasa yang digunakan, serta memenuhi standar bahasa Indonesia yang baik dan benar. Hal ini sejalan dengan standar BSNP. Menurut BSNP buku yang baik memenuhi kriteria meliputi komponen isi, komponen kebahasaan, dan komponen penyajian atau format. Komponen isi meliputi cakupan materi, akurasi materi, kemutakhiran, merangsang keingintahuan, mengembangkan kecakapan hidup, dan mengembangkan wawasan kontekstual. Komponen kebahasaan mencakup kesesuaian dengan tingkat perkembangan peserta didik, komunikatif, dialogis dan interaktif, lugas, komprehensif dan keruntutan alur berpikir, kesesuaian dengan kaidah bahasa Indonesia. Sedangkan komponen penyajian atau format meliputi teknik penyajian, pendukung penyajian materi, dan penyajian pembelajaran.

\section{b. Buku Ajar Siswa}

Pusat Perbukuan (2003) menyatakan bahwa setiap buku pelajaran diharapkan memenuhi standar-standar tertentu yang ditetapkan berdasarkan kebutuhan siswa dan guru, perkembangan ilmu pengetahuan dan teknologi, serta 
tuntutan kurikulum. Standar yang dimaksud dalam pedoman penilaian ini meliputi persyaratan, karakteristik, dan kompetensi minimum yang harus terkandung di dalam suatu buku. Standar penilaian dirumuskan dengan melihat tiga aspek utama, yaitu materi, penyajian, dan bahasa/keterbacaan. Aspek isi meliputi kelengkapan, keakuratan, serta kegiatan yang mendukung materi, kemutakhiran, dan pengorganisasian materi. Aspek penyajian atau format meliputi tampilan umum, tata letak, pemilihan huruf, dan variasi dalam cara menyampaikan materi sedangkan aspek bahasa atau keterbacaan meliputi kejelasan maksud kalimat, kesesuaian bahasa yang digunakan, serta memenuhi standar bahasa Indonesia yang baik dan benar.

Hal ini sejalan dengan standar BSNP. Menurut BSNP buku yang baik memenuhi kriteria meliputi komponen isi, komponen kebahasaan, dan komponen penyajian atau format. Komponen isi meliputi cakupan materi, akurasi materi, kemutakhiran, merangsang keingintahuan, mengembangkan kecakapan hidup, dan mengembangkan wawasan kontekstual. Komponen kebahasaan mencakup kesesuaian dengan tingkat perkembangan peserta didik, komunikatif, dialogis dan interaktif, lugas, komprehensif dan keruntutan alur berpikir, kesesuaian dengan kaidah bahasa Indonesia. Sedangkan komponen penyajian atau format meliputi teknik penyajian, pendukung penyajian materi, dan penyajian pembelajaran.

\section{Lembar Kerja Siswa}

a. Pengertian Lembar Kerja Siswa

Lembar kerja siswa (LKS) ialah lembar kerja yang berisi informasi dan perintah dari guru kepada siswa untuk mengerjakan suatu kegiatan belajar dalam bentuk kerja, praktik, atau dalam bentuk penerapan hasil belajar untuk mencapai tujuan tertentu. Damayanti (2009: 47) menyebut LKS sebagai Lembar Kegiatan Siswa. Lembar Kegiatan Siswa merupakan salah satu bentuk bahan ajar yang berisi tugas yang berkaitan dengan tujuan pembelajaran yang telah ditetapkan dan harus dikerjakan oleh siswa (Damayanti, 2009: 48).

\section{b. Penggunaan Lembar Kerja Siswa di Sekolah}

LKS dapat dianggap sebagai suatu media atau alat pembelajaran, karena dipergunakan guru sebagai perantara dalam melaksanakan kegiatan pengajaran untuk mencapai tujuan instruksional khusus atau tujuan pembelajaran khusus. LKS dikatakan sebagai sarana belajar, karena dengan LKS siswa dapat melaksanakan kegiatan belajar untuk mencapai suatu TIK. Selain itu LKS juga mendorong siswa untuk mengolah sendiri bahan yang dipelajari atau bersama dengan temannya dalam suatu bentuk diskusi kelompok. Suatu kegiatan belajar yang menggunakan LKS memberikan kesempatan penuh kepada siswa untuk mengungkapkan kemampuan dan keterampilan, didorong dan dibimbing berbuat sendiri untuk mengembangkan proses berpikirnya (Tabaitabai, 2009).

\section{c. Fungsi Lembar Kerja Siswa}

Fungsi LKS dalam proses belajar mengajar ada dua, yaitu: (1) dari segi siswa, fungsi LKS adalah sebagai sarana belajar baik di kelas, di ruang praktek maupun di luar kelas sehingga siswa berpeluang besar untuk mengembangkan kemampuan, menerapkan pengetahuan, melatih keterampilan, memproses sendiri untuk mendapatkan perolehannya; dan (2) dari segi guru, melalui LKS, guru 
dalam menyelenggarakan kegiatan belajar mengajar sudah menerapkan metode "membelajarkan siswa" dengan kadar SAL (student active learning) yang tinggi.

\section{d. Komponen Lembar Kerja Siswa}

LKS yang baik seharusnya disusun sedemikian rupa sehingga siswa dapat memahami tugas yang dimaksud dan menyelesaikan tugas tersebut dengan baik. Hal-hal yang perlu diperhatikan antara lain adalah aspek format, aspek isi atau materi, dan aspek kebahasaan. Aspek format meliputi kejelasan pembagian materi, daya tarik, kejelasan sistem penomoran, pengaturan ruang atau tata letak, kesesuaian jenis dan ukuran huruf yang ditampilkan, serta kesesuaian ukuran fisik dengan siswa. Aspek isi meliputi kebenaran isi atau materi, keesensialan materi, pengelompokan bagian-bagiannya logis, dan kesesuaian. Isi dengan strategi pembelajaran, kesesuaian tugas dengan urutan materi dan berperan dalam mendorong siswa dalam upaya menemukan konsep atau prosedur secara mandiri. Sedangkan aspek yang terkait dengan bahasa adalah kebenaran tata bahasa, kesesuaian kalimat dengan taraf berpikir dan kemampuan membaca serta usia siswa, mendorong minat siswa untuk bekerja, kesederhanaan struksur kalimat, ketidakambiguan kalimat, kejelasan petunjuk dan arahan serta bahasa yang digunakan bersifat komunikatif.

\section{Tes Hasil Belajar}

Sesuatu yang baru yang diperoleh siswa dari proses belajar disebut sebagai hasil belajar. Pada dasarnya hasil belajar adalah segala perilaku atau kemampuan yang dimiliki oleh siswa setelah mengikuti kegiatan pembelajaran menyangkut pengetahuan, keterampilan maupun sikap. Untuk melihat hasil belajar diperlukan kegiatan penilaian. Rusijono dan Yulianto (2008:9) menyatakan bahwa penilaian suatu kompetensi dasar dilakukan berdasarkan indikator-indikator pencapaian hasil belajar baik berupa domain kognitif, afektif, maupun psikomotor. Menurut Damayanti (2009: 48) THB adalah salah satu kegiatan yang dapat dilakukan oleh guru untuk melakukan evaluasi atau penilaian. Evaluasi merupakan kegiatan yang tidak bisa terpisah dari kegiatan pembelajaran. Hairuddin (2008: 4) menyatakan bahwa evaluasi berfungsi untuk memberikan informasi kemajuan hasil belajar siswa secara individu dalam mencapai tujuan sesuai kegiatan yang dilakukan, merupakan alat informasi untuk membina kegiatan belajar mengajar lebih lanjut dan alat informasi yang dapat digunakan guru untuk mengetahui tingkat kemampuan siswa, alat untuk memberi motivasi kepada siswa untuk semakin giat dalam belajar, alat untuk memberi informasi tentang semua aspek kemajuan siswa, serta alat untuk memberi bimbingan yang tepat untuk memilih sesuatu sesuai minat, bakat, dan keterampilan yang dimiliki oleh siswa.

Penilaian bisa dilakukan dengan cara tes dan nontes. Penggunaan kedua teknik tersebut tergantung dari tujuan penilaian dan informasi yang ingin diperoleh. Teknik tes digunakan untuk menjaring kemampuan kognitif siswa sedangkan teknik non tes biasanya digunakan untuk melihat aspek psikomotor dan afektif yang tidak terkait dengan aspek kognitif. Informasi yang diperoleh melalui teknik tes biasanya bersifat kuantitatif sedangkan informasi yang diperoleh melalui teknik nontes merupakan data kualitatif. Oleh karena itu untuk mengetahui penguasaan siswa terhadap materi pembelajaran yang sudah disampaikan dalam proses pembelajaran, digunakan tes hasil belajar. Bentuk soal 
tes tertulis ada dua macam yaitu objektif dan subjektif. American Education Reform menyatakan bahwa soal-soal pilihan ganda tidak dapat digunakan untuk menguji kemampuan berpikir tingkat tinggi, kemampuan problem solving, kreativitas, dan sikap inisiatif (Tabaitabai, 2009).

Jenis soal pilihan ganda hanya dapat melatih kemampuan berpikir tingkat rendah seperti menghafal. Wahyudin (2006: 110) menyatakan bahwa ada dua hal yang harus diperhatikan dalam menulis soal. Kedua hal tersebut adalah kisi-kisi soal dan kaidah penulisan soal. Kisi-kisi soal harus mampu mengungkap indikator hasil belajar yang ingin diukur. Sedangkan kaidah penulisan soal berkaitan dengan pedoman yang harus diikuti agar soal yang dihasilkan memiliki kualitas yang baik. Berdasarkan penjelasan tersebut maka validasi yang dilakukan terhadap soal tertulis meliputi validitas yang terkait dengan isi, kebahasaan, serta kesimpulan umum dari keduanya.

\section{METODE PENELITIAN}

\section{Jenis Penelitian}

Penelitian ini termasuk dalam jenis penelitian pengembangan. Adapun yang dikembangkan adalah perangkat pembelajaran terpadu kelas 3 SD di wilayah kabupaten Madiun berbasis kearifan lokal.

\section{Tempat dan Waktu Penelitian}

Penelitian ini dilaksanakan di SDN 2 dan 4 Balerejo Kabupaten Madiun. Kedua SD tersebut dipilih karena karakteristiknya mirip, terletak pada satu sub rayon dan kompleks yang sama sehingga latar belakang lingkungan sosial budaya keduanya mirip. Waktu penelitian dimulai Januari 2012 sampai dengan Juli 2012. Waktu penelitian diambil dengan penyesuaian terhadap jadwal sekolah. Dengan asumsi pengembangan perangkat dilakukan selama 2 bulan selanjutnya validasi ahli dan revisi selama 2 bulan dan uji coba terbatas, revisi, serta uji coba luas dilakukan selama 2 bulan dan penulisan laporan selama 2 bulan.

\section{Subjek Penelitian}

Subjek penelitian adalah kelas 3 SDN 2 dan 4 Balerejo Kabupaten Madiun. Kelas 3 dipilih sebagai subjek peneltian sebab materi pada kelas tiga merupakan materi lanjut dari dasar yang diperoleh pada kelas 2 dan 1 sehingga membutuhkan analisis yang lebih sulit dibandingkan tematis pada kelas 2 dan 1 . Selain itu anak kelas 3 SD sudah memiliki pengetahuan yang lebih kompleks serta penguasaan kosakata yang lebih luas dibandingkan dengan dua kelas sebelumnya sehingga proses komunikasi antara peneliti dengan subjek penelitian akan lebih mudah dilakukan. Uji coba terbatas dilakukan pada sepuluh orang siswa kelas 3 di SDN 4 balerejo sedangkan uji luas dilakukan pada semua siswa kelas 3 di SDN 2 Balerejo.

\section{Prosedur Penelitian}

Dalam pelaksanaan penelitian ini diperlukan dua perangkat pokok, yaitu perangkat pembelajaran terpadu berbasis kearifan lokal dan instrumen pengamatan. Prosedur penelitian dilakukan meliputi beberapa tahap, yaitu: pengembangan perangkat pembelajaran, validasi perangkat, dan ujicoba 
perangkat. Model pengembangan perangkat yang digunakan mengacu pada pengembangan perangkat pembelajaran model Dick and Carey.

\section{Pengembangan Perangkat Pembelajaran}

Penelitian ini menggunakan model pengembangan perangkat Dick dan Carey. Pemilihan tersebut didasarkan pada prinsip perancangan pengembangan perangkat pembelajaran yang dimodelkan Dick dan Carey relevan dengan prinsip dalam KTSP. Pada sistem KTSP, sekolah memiliki full authority and responsibility dalam menetapkan kurikulum dan pembelajaran sesuai dengan visi, misi, dan tujuan satuan pendidikan. Untuk mewujudkan visi, misi dan tujuan tersebut, sekolah dituntut untuk mengembangkan SK dan KD ke dalam indikator kompetensi, mengembangkan strategi, menentukan prioritas, mengendalikan pemberdayaan berbagai potensi sekolah dan lingkungan sekitar, serta mempertanggungjawabkannya kepada masyarakat dan pemerintah.

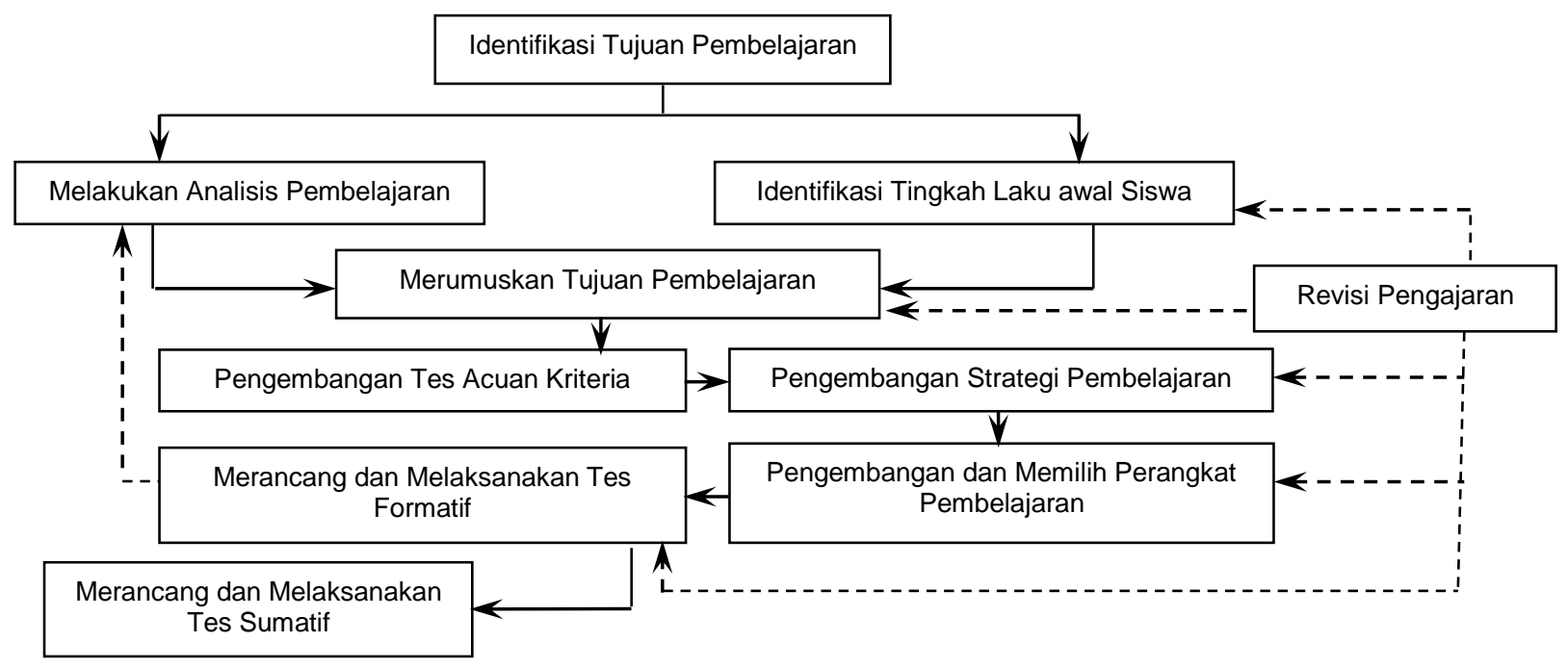

\section{Gambar 1 Rancangan Penelitian dan Pengembangan}

Tahapan perancangan dan pengembangan model Dick, yaitu: (1) identifikasi tujuan pembelajaran (identify instructionnal goals); (2) desain pembelajaran dengan melakukan analisis instruksional/pembelajaran (conduct instructional analysis); (3) mengidentifikasi tingkah laku dan karakteristik awal siswa (identify entry behaviors, characteristics); (4) merumuskan tujuan pembelajaran (write performance objective); (5) mengembangkan butir tes acuan patokan (develop creterion referenced test items); (6) mengembangkan strategi pembelajaran (develop instructonal strategy); (7) mengembangkan dan memilih bahan-bahan pembelajaran (develop and select instructional materials); (8) merangcang dan melaksanakan evaluasi formatif (design and conduct foemative evaluation); (9) revisi pembelajaran (revisi instruction); dan (10) merancang dan melaksanakan eveluasi sumatif (design and conduct summative evaluation).

\section{HASIL DAN PEMBAHASAN}

1. Hasil Penelitian

a. Proses Pengembangan Perangkat Pembelajaran 
Pengembangan perangkat pembelajaran terpadu berbasis kearifan lokal dimulai dengan observasi awal sebagai bahan untuk mengidentifikasi tujuan pembelajaran yang ingin dicapai serta kebudayaan lokal yang bisa ditarik ke dalam pembelajaran. Selanjutnya dilakukan analisis pembelajaran, analisis karakteristik siswa, perumusan tujuan pembelajaran, penyusunan tes hasil belajar pembelajaran terpadu, pengembangan silabus RPP, buku pegangan guru, buku pegangan siswa, dan LKS pembelajaran terpadu, dan evaluasi pembelajaran. Dari kegiatan tersebut diputuskan bahwa permainan Dor-Doran (tebak kata tradisional) yang dikenal secara luas oleh siswa digunakan sebagai center untuk menjembatani pembelajaran terpadu dalam kelas. Perangkat yang dihasilkan disebut sebagai draft 1.

Selanjutnya dilakukan validasi terhadap draft 1 . Validasi dilakukan oleh dua orang pakar untuk melihat validitas isi dan konstruk perangkat yang telah dihasilkan. Selanjutnya perangkat kembali direvisi sesuai dengan masukan dari ahli dan disebut sebagai draft 2 yang diuji coba terbatas pada 10 siswa SDN 2 Balerejo untuk melihat keterlaksanaan perangkat yang telah dihasilkan. Uji coba terbatas ini berlangsung 2 kali pertemuan. Selanjutnya dari uji coba 1 dilakukan analisis terhadap perangkat pembelajaran yang telah dihasilkan sehingga diketahui persentase keterlaksanaan perangkat. Nilai persentase ini selanjutnya dideskripsikan dan didiskusikan dengan pengamat untuk digunakan sebagai masukan pada perangkat draft dua sehingga perangkat menjadi lebih sempurna untuk diujikan pada uji luas (draft 3). Uji luas dilaksanakan dalam dua kali pertemuan kepada 30 siswa yang terlibat dalam pembelajaran. Selanjutnya hasil uji coba dianalisis dan didiskusikan dengan pengamat yang digunkan sebagai masukan untuk memperbaiki perangkat sehingga menjadi produk akhir pengembangan berupa perangkat pembelajaran terpadu dengan memanfaatkan permainan tebak kata tradisional Dor-Doran.

\section{b. Deskripsi Kualitas Hasil Pengembangan}

Untuk menentukan kualitas hasil pengembangan perangkat pembelajaran dilakukan validasi perangkat pembelajaran. Hasil perangkat pembelajaran yang dikembangkan oleh peneliti mengacu pada model pengembangan perangkat pembelajaran Dick and Carey.

\section{1) Kualitas Rencana Pelaksanaan Pembelajaran}

Validasi yang diberikan validator meliputi format, bahasa, dan isi RPP. Berdasarkan Tabel 1 diketahui bahwa rata-rata skor validasi kelayakan RPP dari dua validator memberikan validitas baik. Hal ini menunjukkan bahwa RPP yang dikembangkan dapat digunakan dengan sedikit revisi. Artinya secara isi dan konstruk RPP yang dikembangkan berkualitas. Adapun saran yang diberikan oleh validator satu secara umum adalah memperjelas materi dalam RPP. Hal ini ditindaklanjuti dengan melampirkan materi yang akan digunakan dalam pembelajaran, sebab semula materi yang dicantumkan hanya berupa materi pokok tanpa ada penjelasan lebih lanjut. Sedangkan saran dari validator dua adalah perbaikan aspek bahasa yang difokuskan pada EYD dan pembenahan pada format font (untuk judul dan subjudul) harus digunakan ukuran yang berbeda dari isi. Hal ini ditindaklanjuti dengan membenahi aspek ejaan dan mengubah format font RPP. 
Tabel 1 Hasil Validasi Kelayakan Rencana Pelaksanaan Pembelajaran

\begin{tabular}{|c|c|c|c|c|c|}
\hline \multirow[t]{2}{*}{ No } & \multirow{2}{*}{$\begin{array}{c}\text { Kategori yang } \\
\text { dinilai }\end{array}$} & \multicolumn{2}{|c|}{$\begin{array}{c}\text { Rata-Rata Skor Penilaian } \\
\text { Validator }\end{array}$} & \multirow{2}{*}{$\begin{array}{l}\text { Rata- } \\
\text { rata }\end{array}$} & \multirow{2}{*}{$\begin{array}{c}\text { Keterangan skala } \\
\text { penilaian }\end{array}$} \\
\hline & & Validator 1 & Validator 2 & & \\
\hline 1 & Format & 4,33 & 4 & 4,17 & 1 : berarti tidak baik \\
\hline 2 & Isi & 5 & 4,5 & 4,75 & 2 : berarti kurang baik \\
\hline 3 & Bahasa & 4 & 3,5 & 3,75 & 3 : berarti cukup baik \\
\hline & Rata-rata & 4,44 & 4 & 4,22 & 4 : berarti baik \\
\hline & Kategori & Baik & Baik & Baik & 5 : berarti sangat baik \\
\hline
\end{tabular}

\section{2) Kualitas Media Pembelajaran}

Validasi yang diberikan untuk media pembelajaran ini meliputi aspek kemudahan penggunaan, kemenarikan, dan fleksibilitas. Berdasarkan Tabel 2 diketahui bahwa rata-rata skor validasi kelayakan media dari dua validator memberikan validasi baik. Hal ini menunjukkan media yang dikembangkan dapat digunakan dengan sedikit revisi. Berarti pula secara media yang dihasilkan berkualitas. Adapun saran yang diberikan oleh validator satu secara umum adalah pemberian petunjuk yang sangat jelas bagi siswa sehingga permainan ini akan mudah diikuti oleh siswa. Sedangkan validator kedua menyatakan bahwa kemenarikan dari media ini kurang nampak oleh karena itu perlu dieksplisitkan bahwa permainan ini adalah sesuatu yang bisa dilakukan dengan menyenangkan dan seru. Kedua saran validator tersebut ditindaklanjuti dengan memperjelas dan menyederhanakan kalimat petunjuk permainan tebak kata tradisional "Dor-Doran" dan melombakan skor permainan tersebut ketika berada di dalam pembelajaran.

Tabel 2 Hasil Validasi Kelayakan Media Pembelajaran

\begin{tabular}{|c|c|c|c|c|c|}
\hline \multirow[t]{2}{*}{ No } & \multirow[t]{2}{*}{$\begin{array}{c}\text { Kategori } \\
\text { yang dinilai }\end{array}$} & \multicolumn{2}{|c|}{$\begin{array}{c}\text { Rata-Rata Skor } \\
\text { Penilaian } \\
\text { Validator } \\
\end{array}$} & \multirow[t]{2}{*}{$\begin{array}{l}\text { Rata- } \\
\text { rata }\end{array}$} & \multirow[t]{2}{*}{ Keterangan skala penilaian } \\
\hline & & $\mathbf{I}$ & II & & \\
\hline 1 & $\begin{array}{l}\text { Kemudahan } \\
\text { penggunaan }\end{array}$ & 5 & 4 & 4,5 & $\begin{aligned} 1: & \text { berarti tidak baik (tidak sesuai indikator } \\
& \text { dan tidak bisa diaplikasikan) }\end{aligned}$ \\
\hline 2 & Kemenarikan & 5 & 4 & 4,5 & $\begin{aligned} 2: & \text { berarti kurang baik (tidak sesuai } \\
& \text { indikator tetapi bisa diaplikasikan) }\end{aligned}$ \\
\hline 3 & Fleksibilitas & 5 & 4 & 4,5 & $\begin{array}{l}3 \text { : berarti cukup baik (sesuai indikator } \\
\text { tetapi tidak bisa diaplikasikan) }\end{array}$ \\
\hline & Rata-rata & 5 & 4 & 4,5 & $\begin{aligned} 4: & \text { berarti baik (sesuai dengan indikator dan } \\
& \text { bisa diaplikasikan) }\end{aligned}$ \\
\hline & Kategori & $\begin{array}{l}\text { Sangat } \\
\text { Baik }\end{array}$ & Baik & Baik & $\begin{array}{l}5: \text { berarti sangat baik (sesuai indikator dan } \\
\text { bisa diaplikasikan maksimal) }\end{array}$ \\
\hline
\end{tabular}

\section{3) Kualitas Buku Pegangan Guru}

Berdasarkan Tabel 3 diketahui bahwa rata-rata skor validasi kelayakan BPG dari dua validator memberikan validasi baik. Hal ini menunjukkan bahwa BPG yang dikembangkan dapat digunakan dengan sedikit revisi artinya BPG yang dihasilkan berkualitas. Dalam hal ini validator satu tidak memberikan saran apapun, sedangkan validator dua memberikan saran agar langkah-langkah yang dilakukan guru dalam pembelajaran dirinci atau diberi keterangan harus mengacu ke mana sehingga lebih eksplisit, selain itu aspek kebahsaan harus dibenahi. Hal ini ditindaklanjuti dengan memberikan keterangan bahwa langkah yang harus dilakukan guru dalam pembelajaran mengacu pada Rencana Pelaksanaan 
pembelajaran sedangkan untuk kebahasaan dilakukan dengan mengecek kembali pengetikan dan penggunaan ejaan pada BPG.

Tabel 3 Hasil Validasi Kelayakan Buku Pegangan Guru

\begin{tabular}{|c|c|c|c|c|c|}
\hline \multirow[t]{2}{*}{ No } & \multirow[t]{2}{*}{$\begin{array}{l}\text { Kategori yang } \\
\text { dinilai }\end{array}$} & \multicolumn{2}{|c|}{$\begin{array}{l}\text { Rata-Rata } \\
\text { Skor } \\
\text { Penilaian } \\
\text { Validator } \\
\end{array}$} & \multirow[t]{2}{*}{$\begin{array}{l}\text { Rata- } \\
\text { rata }\end{array}$} & \multirow[t]{2}{*}{ Keterangan skala penilaian } \\
\hline & & $\mathbf{I}$ & II & & \\
\hline 1 & Format & 4,67 & 4 & 4,33 & $\begin{array}{l}1: \text { berarti tidak baik (tidak sesuai indikator } \\
\text { dan tidak bisa diaplikasikan) }\end{array}$ \\
\hline 2 & Isi & 4,2 & 4,5 & 4,35 & $\begin{array}{l}2: \text { berarti kurang baik (tidak sesuai } \\
\text { indikator tetapi bisa diaplikasikan) }\end{array}$ \\
\hline 3 & Kebahasaan & 4 & 3,5 & 3,75 & $\begin{array}{l}3 \text { : berarti cukup baik (sesuai indikator } \\
\text { tetapi tidak bisa diaplikasikan) }\end{array}$ \\
\hline & Rata-rata & 4,29 & 4 & 4,14 & $\begin{array}{l}4: \text { berarti baik (sesuai dengan indikator dan } \\
\text { bisa diaplikasikan) }\end{array}$ \\
\hline & Kategori & Baik & Baik & Baik & $\begin{array}{l}5 \text { : berarti sangat baik (sesuai indikator dan } \\
\text { bisa diaplikasikan maksimal) }\end{array}$ \\
\hline
\end{tabular}

\section{4) Kualitas Buku Ajar Siswa}

BAS yang divalidasi meliputi komponen kelayakan isi, komponen bahasa, dan komponen penyajian. Hasil validasi kelayakan BAS pada Tabel 4 menunjukkan masing-masing validator memberikan validasi baik. Hal ini menunjukkan BAS dapat digunakan dengan sedikit revisi dan berkualitas. Namun terdapat saran perbaikan mengenai kesesuaian kalimat dengan taraf berpikir anak serta kesalahan ejaan yang terjadi karena kesalahan pengetikan.

\section{Tabel 4 Hasil Validasi Kelayakan Buku Ajar Siswa}

\begin{tabular}{|c|c|c|c|c|c|}
\hline \multirow[t]{2}{*}{ No } & \multirow[t]{2}{*}{$\begin{array}{l}\text { Kategori yang } \\
\text { dinilai }\end{array}$} & \multicolumn{2}{|c|}{$\begin{array}{c}\text { Rata-Rata } \\
\text { Skor } \\
\text { Penilaian } \\
\text { Validator }\end{array}$} & \multirow[t]{2}{*}{$\begin{array}{l}\text { Rata- } \\
\text { rata }\end{array}$} & \multirow[t]{2}{*}{ Keterangan skala penilaian } \\
\hline & & I & II & & \\
\hline 1 & Format & 4,75 & 4 & 4,37 & $\begin{array}{c}1: \text { berarti tidak baik (tidak sesuai indikator } \\
\text { dan tidak bisa diaplikasikan) }\end{array}$ \\
\hline 2 & Isi & 4,6 & 5 & 4,8 & $\begin{aligned} 2: & \text { berarti kurang baik (tidak sesuai indikator } \\
& \text { tetapi bisa diaplikasikan) }\end{aligned}$ \\
\hline 3 & Kebahasaan & 4 & 3,25 & 3,62 & $\begin{array}{l}3: \text { berarti cukup baik (sesuai indikator tetapi } \\
\text { tidak bisa diaplikasikan) }\end{array}$ \\
\hline & Rata-rata & 4,45 & 4,08 & 4,26 & $\begin{array}{l}4: \text { berarti baik (sesuai dengan indikator dan } \\
\text { bisa diaplikasikan) }\end{array}$ \\
\hline & Kategori & Baik & Baik & Baik & $\begin{array}{l}5: \text { berarti sangat baik (sesuai indikator dan } \\
\text { bisa diaplikasikan maksimal) }\end{array}$ \\
\hline
\end{tabular}

\section{5) Kualitas Lembar Kegiatan Siswa}

Aspek yang divalidasi meliputi format, isi, dan bahasa. Berdasarkan hasil validasi kelayakan LKS seperti pada Tabel 5 menunjukkan rata-rata skor validasi yang diberikan validator masing-masing berkategori baik. Hal ini menunjukkan bahwa LKS yang dikembangkan dapat digunakan pada siswa SD/MI kelas III dengan sedikit revisi. Terkait dengan validasi LKS ini, validator satu tidak memberikan masukan sedangkan validator dua menyarankan agar font diperbesar dan kosakata yang digunakan disesuaikan dengan taraf berpikir anak. Saran 
tersebut ditindaklanjuti dengan mengubah jenis dan ukuran font dari yang semula Times New Roman 12 menjadi Calibri 14.

Tabel 5 Hasil Validasi Kelayakan Lembar Kerja Siswa

\begin{tabular}{|c|c|c|c|c|c|}
\hline \multirow[t]{2}{*}{ No } & \multirow[t]{2}{*}{$\begin{array}{l}\text { Kategori yang } \\
\text { dinilai }\end{array}$} & \multicolumn{2}{|c|}{$\begin{array}{c}\text { Rata-Rata } \\
\text { Skor } \\
\text { Penilaian } \\
\text { Validator }\end{array}$} & \multirow[t]{2}{*}{$\begin{array}{l}\text { Rata- } \\
\text { rata }\end{array}$} & \multirow[t]{2}{*}{ Keterangan skala penilaian } \\
\hline & & I & II & & \\
\hline 1 & Format & 4,75 & 4 & 4,37 & $\begin{array}{l}1: \text { berarti tidak baik (tidak sesuai indikator } \\
\text { dan tidak bisa diaplikasikan) }\end{array}$ \\
\hline 2 & Bahasa & 3,8 & 4 & 4,8 & $\begin{aligned} 2: & \text { berarti kurang baik (tidak sesuai indikator } \\
& \text { tetapi bisa diaplikasikan) }\end{aligned}$ \\
\hline 3 & Isi & 4 & 3,25 & 3,62 & $\begin{array}{l}3: \text { berarti cukup baik (sesuai indikator tetapi } \\
\text { tidak bisa diaplikasikan) }\end{array}$ \\
\hline & Rata-rata & 4,45 & 4,18 & 3,96 & $\begin{array}{l}4: \text { berarti baik (sesuai dengan indikator dan } \\
\text { bisa diaplikasikan) }\end{array}$ \\
\hline & Kategori & Baik & Baik & Baik & $\begin{array}{l}5: \text { berarti sangat baik (sesuai indikator dan } \\
\text { bisa diaplikasikan maksimal) }\end{array}$ \\
\hline
\end{tabular}

\section{6) Kualitas Tes Hasil Belajar}

Validator memberikan validasi terhadap THB meliputi tiga kategori yaitu validitas isi, bahasa, dan penulisan. Hasil validasi kelayakan THB disajikan dalam Tabel 6. Berdasarkan Tabel 6 dapat disimpulkan bahwa tes hasil belajar yang dikembangkan valid, dapat dipahami, dan dapat digunakan dengan revisi.

Tabel 6 Hasil Validasi Kelayakan Tes Hasil Belajar

\begin{tabular}{|c|c|c|c|c|c|c|c|c|}
\hline \multirow{3}{*}{ No } & \multicolumn{7}{|c|}{ Validitas } & \multirow{3}{*}{$\begin{array}{l}\mathrm{V}: \text { Valid } \\
\mathrm{Cv}: \text { Cukup valid } \\
\mathrm{Kv}: \text { Kurang valid } \\
\mathrm{Tv}: \text { Tidak valid }\end{array}$} \\
\hline & \multicolumn{2}{|c|}{$\begin{array}{c}\text { Validitas } \\
\text { Isi }\end{array}$} & \multicolumn{2}{|c|}{$\begin{array}{c}\text { Bahasa dan } \\
\text { Penulisan } \\
\text { Soal } \\
\end{array}$} & \multicolumn{2}{|c|}{$\begin{array}{c}\text { Kesimpulan } \\
\text { dari } \\
\text { Validator }\end{array}$} & \multirow[t]{2}{*}{$\begin{array}{c}\text { Simpulan } \\
\text { Peneliti }\end{array}$} & \\
\hline & I & II & I & II & I & II & & \\
\hline 1 & $\mathrm{~V}$ & $\mathrm{~V}$ & Sdp & Sdp & $\mathrm{Rk}$ & $\mathrm{Rk}$ & Revisi & Bahasa \& Penulisan Soal \\
\hline 2 & $\mathrm{~V}$ & $\mathrm{~V}$ & Sdp & Sdp & $\mathrm{Rk}$ & $\mathrm{Rk}$ & Revisi & Sdp : Sangat dapat dipahami \\
\hline 3 & $\mathrm{~V}$ & V & Sdp & Sdp & $\mathrm{Rk}$ & $\mathrm{Rk}$ & Revisi & Dp : Dapat dipahami \\
\hline 4 & $\mathrm{~V}$ & $\mathrm{~V}$ & Sdp & Sdp & Rk & $\mathrm{Rk}$ & Revisi & Kdp : Kurang dapat dipahami \\
\hline 5 & $\mathrm{~V}$ & $\mathrm{~V}$ & Sdp & Sdp & Rk & $\mathrm{Rk}$ & Revisi & Tdp : Tidak dapat dipahami \\
\hline 6 & $\mathrm{~V}$ & $\mathrm{~V}$ & Sdp & $\mathrm{Dp}$ & $\mathrm{Rk}$ & $\mathrm{Rk}$ & Revisi & Kesimpulan \\
\hline 7 & $\mathrm{~V}$ & $\mathrm{~V}$ & Sdp & Sdp & $\mathrm{Rk}$ & $\mathrm{Rk}$ & Revisi & $\operatorname{Tr}$ : Dapat digunakan tanpa revisi \\
\hline 8 & $\mathrm{~V}$ & $\mathrm{~V}$ & Sdp & Sdp & $\mathrm{Rk}$ & $\mathrm{Rk}$ & Revisi & Rk : Dapat digunakan dengan revisi kecil \\
\hline 9 & $\mathrm{~V}$ & $\mathrm{~V}$ & Sdp & Sdp & Rk & $\mathrm{Rk}$ & Revisi & $\mathrm{Rb}$ : Dapat digunakan dengan revisi besar \\
\hline 10 & $\mathrm{~V}$ & $\mathrm{~V}$ & Sdp & Sdp & $\mathrm{Rk}$ & $\mathrm{Rk}$ & Revisi & $\begin{aligned} \mathrm{Pk}: & \text { Belum dapat digunakan, masih perlu } \\
& \text { konsultasi }\end{aligned}$ \\
\hline
\end{tabular}

\section{c. Deskripsi Impementasi Permainan Tebak Kata Tradisional Dor-Doran dalam Pembelajaran Terpadu}

Perangkat pembelajaran yang telah dikembangkan selanjutnya diujicobakan pada SDN 2 dan 4 Balerejo Kabupaten Madiun. Uji terbatas dilakukan di SDN 2 Balerejo pada bulan April 2012 selanjutnya dari uji terbatas dilakukan revisi dan uji coba luas pada kurun waktu Juni 2012. Adapun hasil uji terbatas dan luas terangkum sebagai berikut.

1) Deskripsi Keterlaksanaan Rencana Pembelajaran Terpadu di Kelas III dengan Menggunakan Permainan Tebak kata Tradisional Dor-Doran 
Deskripsi keterlaksanaan rencana pembelajaran terpadu di kelas III dengan menggunakan permainan tebak kata tradisional dor-doran terdiri dari dua aspek, yaitu: (1) hasil pengamatan keterlaksanaan RPP pertemuan 1 ujicoba 1 dan 2; dan (2) hasil pengamatan keterlaksanaan RPP pertemuan 2 ujicoba 1 dan 2. Hasil pengamatan keterlaksanaan RPP pertemuan 1 ujicoba 1 dan 2 ditampilkan pada Tabel 7.

Tabel 7 Hasil Pengamatan Keterlaksanaan RPP Pertemuan 1 Ujicoba 1 dan 2

\begin{tabular}{|c|c|c|c|c|c|}
\hline \multirow{3}{*}{ No } & \multirow{3}{*}{ Aspek yang Diamati } & \multicolumn{4}{|c|}{ PENILAIAN } \\
\hline & & \multicolumn{2}{|c|}{ U 1} & \multicolumn{2}{|c|}{$\mathbf{U} 2$} \\
\hline & & P1 & $\mathbf{P 2}$ & P1 & $\mathbf{P 2}$ \\
\hline \multirow{4}{*}{$\mathbf{A}$} & Pendahuluan & & & & \\
\hline & $\begin{array}{l}\text { 1. Mengondisikan siswa agar siap mengikuti pembelajaran } \\
\text { dengan membagi siswa menjadi beberapa kelompok } \\
\text { dengan jumlah berimbang }\end{array}$ & 3 & 4 & 4 & 4 \\
\hline & $\begin{array}{l}\text { 2. Melakukan tanya jawab sederhana tentang pengetahuan } \\
\text { siswa tentang memberi petunjuk, operasi hitung, dan } \\
\text { lingkungan }\end{array}$ & 1 & 1 & 3 & 3 \\
\hline & 3. Menginformasikan tujuan pembelajaran pada siswa & 3 & 3 & 3 & 4 \\
\hline & JUMLAH & 7 & 8 & 10 & 11 \\
\hline
\end{tabular}

B Kegiatan Inti

1. Membacakan aturan permainan tebak kata tradisional "Dor-Doran"

2. Siswa dan guru bermain tebak kata tradisional secara klasikal, peran pemberi tebakan dilakukan oleh guru.

3. Siswa menjawab tebakan yang diberikan oleh guru dengan mengacungkan tangan terlebih dahulu.

4. Guru bertanya pada siswa apa saja yang dilakukan saat bermain "Dor-Doran" kemudian guru menarik jawaban siswa pada konsep membuat petunjuk melakukan sesuatu.

5. Permainan tebak kata dilanjutkan oleh kelompok yang telah terbentuk dengan langkah awal Kelompok pertama mendapat tugas untuk mendaftar lingkungan di sekitar sekolah, kelompok dua bertugas mendaftar lingkungan yang sehat dan tidak sehat, kelompok ketiga bertugas mendaftar penyebab lingkungan tidak sehat, kelompok keempat bertugas mendaftar kegiatan yang digolongkan memelihara lingkungan (jumlah kosakata yang ditulis masing-masing kelompok dibatasi 5 kemudian dipilih 1 kata yang akan dibuat petunjuknya untuk ditebakkan pada kelompok lain).

6. Kata yang telah ditulis oleh masing-masing kelompok diberi petunjuk seperti model petunjuk yang dituliskan oleh guru di papan tulis.

7. Guru memeriksa hasil kerja siswa dengan berkeliling dari satu kelompok ke kelompok yang lain. Pekerjaan yang kurang sempurna diberi saran dan disempurnakan.

8. Permainan tebak kata antar kelompok dilakukan.

$\begin{array}{llll}4 & 4 & 4 & 4 \\ 4 & 4 & 4 & 4 \\ 3 & 4 & 4 & 4 \\ 4 & 4 & 4 & 4\end{array}$

$\begin{array}{llll}3 & 4 & 3 & 4\end{array}$

\section{JUMLAH}

C Penutup

1. Memberikan tugas pada masing-masing kelompok sesuai dengan tugas awal, masing-masing anggota kelompok

2. Memberikan kesimpulan dan menyampaikan manfaat pembelajaran

\begin{tabular}{lllllll}
\hline & JUMLAH & 8 & 7 & 8 & 7 \\
\hline D & Pengelolaan Waktu & 3 & 3 & 4 & 3 \\
\hline
\end{tabular}




\begin{tabular}{|c|c|c|c|c|c|}
\hline \multirow{3}{*}{ No } & \multirow{3}{*}{ Aspek yang Diamati } & \multicolumn{4}{|c|}{ PENILAIAN } \\
\hline & & \multicolumn{2}{|c|}{$\mathrm{U} 1$} & \multicolumn{2}{|c|}{$\mathbf{U} 2$} \\
\hline & & P1 & P2 & P1 & P2 \\
\hline \multirow[t]{4}{*}{$\mathbf{E}$} & \multicolumn{5}{|l|}{ Suasana Kelas } \\
\hline & 1. Siswa antusias & 3 & 4 & 4 & 4 \\
\hline & 2. Guru antusias & 4 & 4 & 4 & 4 \\
\hline & 3. KBM sesuai skenario pembelajaran & 3 & 3 & 4 & 3 \\
\hline & JUMLAH & 13 & 14 & 16 & 14 \\
\hline & JUMLAH TOTAL & 57 & 60 & 64 & 63 \\
\hline \multicolumn{2}{|r|}{ Persentase Keterlaksanaan RPP } & 83,82 & 88,24 & 94,12 & 92,65 \\
\hline \multicolumn{2}{|r|}{ Rata-Rata Persentase Keterlaksanaan RPP } & \multicolumn{2}{|c|}{86,03} & \multicolumn{2}{|c|}{93,38} \\
\hline \multirow{2}{*}{\multicolumn{2}{|c|}{ Rata-Rata Persentase Keterlaksanaan RPP U 1 dan U 2}} & \multicolumn{4}{|c|}{$\begin{array}{ll}00,00 & 89,75\end{array}$} \\
\hline & Reliabilitas Instrumen & \multicolumn{2}{|c|}{0,96} & \multicolumn{2}{|c|}{0,96} \\
\hline
\end{tabular}

Hasil Pengamatan Keterlaksanaan RPP Pertemuan 2 Ujicoba 1 dan 2 ditampilkan pada Tabel 8 .

Tabel 8 Hasil Pengamatan Keterlaksanaan RPP Pertemuan 2 Ujicoba 1 dan 2

\begin{tabular}{|c|c|c|c|c|c|}
\hline \multirow{3}{*}{ No } & \multirow{3}{*}{ Aspek yang Diamati } & \multicolumn{4}{|c|}{ PENILAIAN } \\
\hline & & \multicolumn{2}{|c|}{ U1 } & \multicolumn{2}{|c|}{ U2 } \\
\hline & & P1 & P2 & P1 & $\mathbf{P 2}$ \\
\hline \multirow[t]{5}{*}{$\mathbf{A}$} & Pendahuluan & & & & \\
\hline & $\begin{array}{l}\text { 1. Mengondisikan siswa agar siap mengikuti pembelajaran } \\
\text { dengan mengingatkan kembali pada pelajaran pertemuan } \\
\text { sebelumnya. }\end{array}$ & 3 & 4 & 4 & 4 \\
\hline & 2. Menyampaikan tujuan pembelajaran & 3 & 3 & 3 & 3 \\
\hline & 3. Melakukan undian giliran tampil kelompok & 4 & 4 & 4 & 4 \\
\hline & JUMLAH & 10 & 11 & 11 & 11 \\
\hline \multirow[t]{9}{*}{ B } & Kegiatan Inti & & & & \\
\hline & $\begin{array}{l}\text { 1. Membantu siswa bermain Dor-Doran dengan menempel } \\
\text { kartu huruf jawaban siswa }\end{array}$ & 4 & 4 & 4 & 4 \\
\hline & 2. Membuat hubungan antar kosakata yang ada di papan tulis & 4 & 4 & 4 & 4 \\
\hline & $\begin{array}{l}\text { 3. Membimbing siswa mengidentifikasi lingkungan alam dan } \\
\text { buatan, lingkungan sehat dan tidak sehat, penyebab dan cara } \\
\text { memeliharanya }\end{array}$ & 3 & 3 & 4 & 4 \\
\hline & $\begin{array}{l}\text { 4. Memberi kesempatan perwakilan } \\
\text { membacakan hasil identifikasinya, kelompok } \\
\text { mengomentari }\end{array}$ & 4 & 4 & 4 & 4 \\
\hline & $\begin{array}{l}\text { 5. Membuat petunjuk tentang memelihara lingkungan dengan } \\
\text { bergotong royong dengan menganalogi petunjuk bermain } \\
\text { "Dor-Doran" }\end{array}$ & 2 & 3 & 3 & 4 \\
\hline & $\begin{array}{l}\text { 6. Memberi kesempatan siswa untuk menampilkan } \\
\text { pekerjaannya, siswa lain mengomentari }\end{array}$ & 3 & 4 & 4 & 3 \\
\hline & 7. Mengevaluasi hasil kerja siswa & 4 & 4 & 4 & 4 \\
\hline & JUMLAH & 24 & 25 & 27 & 27 \\
\hline \multirow[t]{4}{*}{$\mathbf{C}$} & Penutup & & & & \\
\hline & $\begin{array}{l}\text { 1. Guru menyatakan bahwa siswa dapat mengajarkan } \\
\text { permainan "Dor-Doran" kepada siswa dari kelas lain }\end{array}$ & 4 & 4 & 4 & 4 \\
\hline & $\begin{array}{l}\text { 2. Memberikan simpulan dan menyampaikan manfaat } \\
\text { pembelajaran. }\end{array}$ & 4 & 4 & 4 & 4 \\
\hline & JUMLAH & 8 & 8 & 8 & 8 \\
\hline D & Pengelolaan Waktu & 3 & 3 & 3 & 3 \\
\hline \multirow[t]{5}{*}{$\mathbf{E}$} & Suasana Kelas & & & & \\
\hline & 1. Siswa antusias & 4 & 4 & 4 & 4 \\
\hline & 2. Guru antusias & 4 & 4 & 4 & 3 \\
\hline & 3. KBM sesuai skenario pada RPP & 3 & 3 & 4 & 4 \\
\hline & JUMLAH & 11 & 11 & 15 & 14 \\
\hline
\end{tabular}




\begin{tabular}{|c|c|c|c|c|c|}
\hline \multirow{3}{*}{ No } & \multirow{3}{*}{ Aspek yang Diamati } & \multicolumn{4}{|c|}{ PENILAIAN } \\
\hline & & \multicolumn{2}{|c|}{ U1 } & \multicolumn{2}{|c|}{$\mathrm{U} 2$} \\
\hline & & P1 & P2 & P1 & P2 \\
\hline & JUMLAH TOTAL & 56 & 58 & 61 & 60 \\
\hline \multicolumn{2}{|c|}{ Persentase Keterlaksanaan RPP } & 87,50 & 90,63 & 95,31 & 93,75 \\
\hline \multirow{2}{*}{\multicolumn{2}{|c|}{$\begin{array}{l}\text { Rata-Rata Persentase Keterlaksanaan RPP } \\
\text { Rata-Rata Persentase Keterlaksanaan RPP U } 1 \text { dan U } 2\end{array}$}} & \multirow{2}{*}{\multicolumn{2}{|c|}{87,50}} & \multicolumn{2}{|c|}{$\mathbf{9 4 , 5 3}$} \\
\hline & & & \multicolumn{3}{|c|}{91,01} \\
\hline Reli & & \multicolumn{2}{|c|}{0,98} & & 97 \\
\hline
\end{tabular}

$\begin{array}{llll}\text { Keterangan: P1: Pengamat } 1 & \text { P2: Pengamat } 2 & \text { U 1: Uji Coba } 1 & \text { U2: Uji Coba } 2\end{array}$

Berdasarkan Tabel 7 dan 8 , diketahui bahwa rata-rata persentase keterlaksanaan RPP pertemuan 1 uji coba 1 dan 2 adalah 89,75\% sedangkan ratarata persentase pertemuan 2 uji coba 1 dan 2 adalah 91,01\%. Dari data tersebut diketahui bahwa RPP yang dikembangkan dapat diterapkan dengan baik. Reliabilitas lembar keterlaksanaan RPP pada uji coba 1 pertemuan 1 adalah 0,96 sedangkan pada uji coba 2 pertemuan 1 diperoleh nilai yang sama. Untuk uji coba 1 pertemuan 2 nilai reliabilitas lembar keterlaksanaan RPP adalah 0,98 sedangkan pada uji coba 2 pertemuan 2 adalah 0,97. Dari nilai-nilai tersebut diketahui bahwa koefisien reliabilitas lembar keterlaksanaan pembelajaran lebih tinggi dibanding koefisien reliabilitas yang menjadi patokan sehingga dapat dikatakan bahwa lembar keterlaksanaan RPP ini mempunyai reliabilitas yang tinggi. Secara kualitatif deskripsi keterlaksanaan RPP pada uji coba satu dan dua adalah:

\section{a) Pertemuan 1}

Aspek pertama yang diamati pada keterlaksanaan RPP pertemuan 1, uji coba 1 dan 2 ini adalah aspek pendahuluan yang terdiri dari 3 kegiatan. Kegiatan pertama yang dilakukan adalah mengondisikan siswa agar siap mengikuti pembelajaran dengan membagi siswa menjadi beberapa kelompok dengan jumlah berimbang. Dalam mengondisikan siswa pada uji coba 1, guru tidak mengalami kesulitan berarti sebab jumlah siswa hanya sepuluh orang siswa sehingga dalam waktu yang singkat kelompok telah terbentuk, hanya saja karena siswa harus memilih sendiri kelompoknya maka ada siswa yang sempat tidak mempunyai kelompok sebab tidak ada siswa lain yang mau menjadi satu kelompok dengan siswa tersebut. Menurut pengamat hal ini dikarenakan siswa bersangkutan suka mengacau di dalam kelas sehingga dijauhi oleh teman-temannya. Sedangkan pada uji coba 2 pembagian kelompok berlangsung agak lama, guru membagi kelompok siswa berdasarkan tempat duduknya. Ada beberapa siswa yang protes sebab mendapat kelompok yang tidak sesuai dengan harapannya. Hal ini bisa diatasi setelah guru menyatakan bahwa siapapun kelompoknya semua adalah teman sekelas yang harus dihargai, sebab orang yang tidak mau menghargai orang lain bukanlah anak yang soleh.

Pernyataan tersebut muncul seiring dengan karakter yang ingin ditanamkan sekolah kepada siswa. Kegiatan kedua adalah melakukan tanya jawab sederhana tentang pengetahuan siswa tentang memberi petunjuk, operasi hitung, dan lingkungan. Pada uji coba 1, guru lupa melakukan hal ini dan langsung menginformasikan tujuan pembelajaran kepada siswa sedangkan pada uji coba 2 kegiatan ini muncul. Guru bertanya kepada siswa pernahkah mempelajari hal-hal tersebut di semester 1 dan siswa menjawab sudah. Kemudian guru mengeksplorasi siswa tentang: (1) cara memberikan petunjuk kepada orang lain dengan baik; (2) operasi hitung bilangan; dan (3) kenampakan alam dan buatan serta cara memeliharanya. Jawaban siswa adalah untuk memberi petunjuk harus 
jelas, siswa pernah melakukan operasi hitung penjumlah, pengurangan, perkalian, dan pembagian, kenampakan alam adalah ciptaan Allah sedangkan kenampakan buatan adalah buatan manusia sedangkan untuk memeliharanya maka kita harus menjaganya. Kegiatan ketiga adalah menginformasikan tujuan pembelajaran kepada siswa sesuai dengan RPP yang dikembangkan. Selanjutnya guru meniformasikan bahwa untuk mencapai tujuan pembelajaran akan dilakukan dengan bermain. Kata "bermain" membuat siswa sangat antusias, sehingga suasana kelas menjadi agak gaduh maka untuk mengembalikan kelas pada kondisi konsentrasi guru menginformasikan kepada siswa agar tenang untuk memulai dan skor antar kelompok akan dilombakan.

Aspek selanjutnya yang diamati adalah kegiatan inti. Pada kegiatan inti kegiatan pertama yang dilakukan guru adalah membacakan aturan permainan tebak kata tradisional "Dor-Doran" yang ada dalam BPG. Selanjutnya siswa dan guru melakukan permainan tebak kata secara klasikal, peran pemberi tebakan dilakukan oleh guru sedangkan kelompok siswa sebagai pihak penebak. Setelah permainan tebak kata selesai, guru dan siswa menghitung skor bersama-sama. Anggota kelompok yang menang diberikan penghargaan berupa bintang yang bisa ditempel di baju siswa. Selanjutnya kegiatan pembelajaran dialihkan pada penemuan konsep dengan cara guru memberikan pertanyaan kepada siswa apa saja yag dilakukan saat bermain "Dor-Doran". Pada saat jawaban siswa tidak sesuai dengan apa yang dilakukan, guru meluruskan dengan mengingatkan siswa pada kegiatan yang baru saja dilakukan. Setelah langkah bermain "Dor-Doran" selesai diidentifikasi guru menyuruh siswa untuk membaca ilustrasi pada halaman 5 BAS serta menjawab pertanyaan pada halaman 7 BAS. Guru menugaskan pertanyaan yang ada di halaman 7 BAS dengan bertanya secara lisan kepada siswa apa yang terjadi jika langkah-langkah yang ditulis kemudian diinformasikan kepada orang lain tidak lengkap, tidak jelas, dan tidak urut bisakah orang yang diberi informasi bermain "Dor-Doran" seperti yang baru saja dilakukan. Siswa menjawab tidak mungkin bisa kecuali orangnya telah melihat contoh bermain "Dor-Doran" dari jawaban siswa tersebut, guru mengarahkan siswa agar menyimpulkan bahwa petunjuk yang baik harus memenuhi syarat jelas, urut, dan lengkap begitu juga ketika siswa membuat petunjuk untuk bermain tebak kata tradisional "Dor-Doran".

Kegiatan dilanjutkan dengan permainan tebak kata yang dilakukan oleh siswa secara berkelompok. Langkah awal yang dilakukan adalah kelompok siswa diberi tugas yang berbeda oleh guru sehingga kata yang ditebakkan oleh masingmasing kelompok berbeda. Adapun tugas yang diberikan oleh guru tertuang pada LKS halaman 3-6. Karena pada uji coba 2 terdapat 8 kelompok maka kelompok 1 dan kelompok 8 mengerjakan tugas 1 sedangkan kelompok 2 dan kelompok 7 mengerjakan tugas 2, kelompok 3 dan 6 mengerjakan tugas 3, kelompok 4 dan 5 mengerjakan tugas 4. Kata yang telah ditulis oleh kelompok dibatasi 5 buah. Selanjutnya masing-masing kelompok memilih satu kata yang akan ditebakkan. Kata yang telah dipilih diberi petunjuk sesuai dengan model petunjuk yang telah dituliskan oleh guru di papan tulis. Guru memeriksa hasil kerja siswa dengan berkeliling dari satu kelompok ke kelompok yang lain. Pekerjaan yang kurang sempurna diberi saran dan disempurnakan. Permainan tebak kata antar kelompok dilakukan. Pada uji coba 2 dalam kegiatan ini terjadi kekacauan di kelas sebab masing-masing kelompok ingin menang sendiri sehingga guru menerapkan aturan 
straples mulut. Bagi kelompok yang melanggar aturan, tidak mau mengacungkan tangan terlebih dahulu ketika menjawab, harus menutup mulutnya dengan tangan dan dilarang ikut permainan. Hal yang sama dilakukan juga pada kelompok yang gagal menjawab pada petunjuk yang dimaksut. Kelompok yang dihukum baru boleh ikut bermain jika ada kelompok lain yang kena hukuman.

Aspek selanjutnya yang diamati adalah penutup. Pada kegiatan ini, guru memberikan tugas rumah pada masing-masing kelompok untuk membuat petunjuk tebakan pada kata-kata rahasia yang telah disediakan oleh guru. Pada awalnya di RPP guru ini merencanakan untuk memberikan tugas sesuai tugas awal yang harus dilakukan siswa tetapi karena guru khawatir kata yang dipilih siswa tidak akan mengarah pada konsep yang ingin diberikan pada pertemuan selanjutnya, guru berimprovisasi dengan memberikan kata rahasia dan kelompok siswa bertugas untuk membuat petunjuknya saja. Terjadi kelebihan waktu sebanyak sepuluh menit pada pertemuan satu uji coba 2 , hal ini dikarenakan guru kurang menguasai pengelolaan kelas besar sehingga seringkali guru berhenti untuk mengondisikan siswa. Suasana kelas yang teramati rata-rata siswa sangat antusias hal ini terlihat dari banyaknya siswa yang berebut untuk menjawab pertanyaan guru sampai lupa pada aturan untuk menunggu guru menunjuk lebih dahulu siswa yang mengacungkan tangan. Guru juga antusias dalam pembelajaran. KBM sesuai dengan skenario pembelajaran meskipun guru harus melakukan beberapa improvisasi.

\section{b) Pertemuan 2}

Aspek pendahuluan pada pertemuan 2 dilakukan dengan terlebih dahulu mengondisikan siswa agar siap mengikuti pembelajaran dengan mengingatkan siswa pada pelajaran pertemuan sebelumnya. Selanjutnya guru menyampaikan tujuan pembelajaran dan melakukan undian giliran tampil kelompok. Pada kegiatan pendahuluan ini guru juga mengingatkan siswa untuk duduk sesuai dengan kelompoknya minggu lalu. Tidak terdapat maslah pada uji coba 1 maupun uji coba 2 untuk aspek pendahuluan ini. Aspek inti dilakukan dengan bermain "Dor-Doran" secara berkelompok. Kelompok pemberi tebakan tampil secara bergiliran ke depan kelas sedangkan guru membantu kelompok dengan bertindak sebagai juri dan menempel kartu huruf yang merupakan jawaban siswa. Karena khawatir terjadi kekacauan yang sama dengan pertemuan 1 maka pada uji coba 2 sebelum permainan tebak kata antar kelompok berlangsung, guru mengingatkan siswa pada peraturan straples mulut. Setelah itu permainan berlangsung tanpa ada kendala yag berarti. Setelah masing-masing kelompok tampil, guru membimbing siswa untuk membuat hubungan antar kosakata yang ada di papan tulis dengan melontarkan pertanyaan pancingan.

Contoh kegiatan ini adalah sebagai berikut. "Kosakata yang tertera di papan tulis: lingkungan, alam, buatan maka guru bertanya kepada siswa "kira-kira ada berapa jenis lingkungan yang ada di sekitar kita?". Selanjutnya guru menugaskan siswa untuk membaca BAS halaman 10, sehingga siswa mampu mengidentifikasi bahwa jenis lingkungan ada dua yaitu lingkungan alam dan buatan sekaligus tahu contoh lingkungan alam dan buatan”. Selanjutnya guru memberikan kesempatan kepada masing-masing kelompok untuk mendiskusikan jawaban lain dari masing-masing pertanyaan yang ada di LKS halaman 3-6. Setelah kegiatan diskusi kelompok untuk mengidentifikasi lingkungan alam dan 
buatan, lingkungan sehat dan tidak sehat, penyebab dan cara memeliharanya, perwakilan kelompok menampilkan hasil kerja kelompoknya, kelompok lain memberikan komentar dengan menambahkan atau menyangkal jawaban kelompok yang tampil. Kegiatan dilanjutkan dengan kegiatan individu untuk membuat petunjuk tentang memelihara lingkungan dengan bergotong royong dengan menganalogi petunjuk bermain "Dor-Doran". Beberapa siswa diberi kesempatan menampilkan pekerjaannya dan dikomentari oleh siswa lain. Guru memberikan evaluasi, komentar dan saran. Aspek selanjutnya pada pertemuan 2 adalah penutup dalam hal ini guru menutup pelajaran dengan memberikan simpulan dan menyampaikan manfaat pembelajaran kepada siswa. Guru juga menanyakan kepada siswa apakah siswa merasa senang dengan permainan "DorDoran", siswa menjawab bahwa mereka merasa senang maka guru mengatakan bahwa setelah pembelajaran ini, siswa dapat mengajarkan permainan "DorDoran" kepada siswa lain di luar kelas mereka atau kepada teman bermain di rumah sehingga mereka bisa bermain "Dor-Doran" bersama.

2) Deskripsi Respons Siswa Terhadap Permainan Tebak Kata Tradisional "DorDoran" sebagai Media Pembelajaran Terpadu

Data respons siswa terhadap permainan tebak kata tradisional "dor-doran" sebagai media pembelajaran terpadu ditampilkan pada Tabel 9.

Tabel 9 Persentase Hasil Respons Siswa Uji Coba 1 dan 2

\begin{tabular}{|c|c|c|c|c|c|c|c|c|c|c|c|c|}
\hline \multirow{3}{*}{ No } & \multirow{3}{*}{ Aspek } & \multirow{3}{*}{$\begin{array}{l}\text { Indi- } \\
\text { kator }\end{array}$} & \multicolumn{10}{|c|}{ Persentase } \\
\hline & & & \multicolumn{5}{|c|}{ Uji 1} & \multicolumn{5}{|c|}{ Uji 2} \\
\hline & & & STS & TS & RR & $\mathbf{S}$ & SS & STS & $\mathbf{T}$ & $\mathbf{R R}$ & $\mathbf{S}$ & SS \\
\hline \multirow[t]{8}{*}{1} & Ketertarikan siswa & $\mathrm{A}$ & 0 & 0 & 10 & 30 & 60 & 0 & 0 & 6,7 & 33,3 & 60 \\
\hline & terhadap media & B & 0 & 0 & 0 & 50 & 50 & 0 & 0 & 0 & 53,3 & 16,7 \\
\hline & pembelajaran & $\mathrm{C}$ & 0 & 0 & 20 & 40 & 40 & 0 & 0 & 10 & 40 & 50 \\
\hline & & $\mathrm{D}$ & 0 & 0 & 0 & 40 & 60 & 0 & 0 & 3,3 & 33,3 & 63,3 \\
\hline & & $\mathrm{E}$ & 0 & 0 & 0 & 70 & 30 & 0 & 0 & 6,7 & 70 & 23,3 \\
\hline & & $\mathrm{F}$ & 0 & 0 & 20 & 70 & 10 & 0 & 0 & 6,7 & 73,3 & 20 \\
\hline & & G & 0 & 0 & 0 & 40 & 60 & 0 & 0 & 0 & 40 & 60 \\
\hline & & $\mathrm{H}$ & 0 & 0 & 20 & 60 & 20 & 0 & 0 & 6,7 & 56,7 & 36,7 \\
\hline \multicolumn{3}{|c|}{ Persentase Ketertarikan } & $\mathbf{0}$ & $\mathbf{0}$ & 8,75 & 50 & 41,25 & $\mathbf{0}$ & $\mathbf{0}$ & 5 & 50 & 41,25 \\
\hline \multirow[t]{7}{*}{2} & Kemudahan & A & 0 & 10 & 10 & 50 & 30 & 0 & 3,3 & 3,3 & 63,3 & 30 \\
\hline & penyerapan materi & B & 0 & 0 & 0 & 50 & 50 & 0 & 0 & 0 & 50 & 50 \\
\hline & setelah & $\mathrm{C}$ & 0 & 0 & 10 & 40 & 50 & 0 & 0 & 6,7 & 36,7 & 56,7 \\
\hline & menggunakan & $\mathrm{D}$ & 0 & 0 & 0 & 60 & 40 & 0 & 0 & 0 & 60 & 40 \\
\hline & media & $\mathrm{E}$ & 0 & 0 & 0 & 70 & 30 & 0 & 0 & 0 & 70 & 30 \\
\hline & Persentase Kemuda & & $\mathbf{0}$ & 2 & 4 & 54 & 40 & $\mathbf{0}$ & $\mathbf{0 , 7}$ & 2 & 56 & 41,33 \\
\hline & Rata-Rata Persent & & $\mathbf{0}$ & 1 & 6,37 & 52 & 40,6 & $\mathbf{0}$ & $\mathbf{0 , 3}$ & 3,5 & 53 & 41,2 \\
\hline
\end{tabular}

\section{Deskripsi Indikator:}

\section{A. Aspek ketertarikan}

1. Pembelajaran seperti ini baru dilakukan di kelas saya

2. Saya tertarik pada pembelajaran ini

3. Hal-hal yang saya pelajari dalam pembelajaran ini akan bermanfaat bagi saya

4. Teman-teman saya ingin tahu terhadap materi pelajaran

5. Saya senang bekerja dalam pembelajaran ini

6. Saya merasa puas dengan apa yang saya peroleh dari pembelajaran ini

7. Guru mengajar dengan menarik

8. Saya merasa dihargai dalam pembelajaran ini 


\section{B. Aspek kemudahan}

1. Saya tahu hubungan antara isi materi pelajaran ini dengan sesuatu yang telah saya ketahui

2. Saya merasa lebih mudah memahami materi yang ada setelah saya mengikuti pelajaran ini.

3. Saya merasa yakin bisa menjawab pertanyaan yang diajukan oleh guru tentang materi pembelajaran ini.

4. Saya merasa bisa mengerjakan semua soal yang terkait dengan pelajaran ini

5. Guru membimbing kami dengan baik sehingga materi pelajaran ini terasa mudah

Berdasarkan Tabel 9 diperoleh data bahwa pada uji coba 1 rata-rata persentase siswa sangat tidak setuju bahwa media ini menarik dan mempermudah pembelajaran adalah 0\%; siswa yang menganggap media tidak menarik dan tidak mempermudah pembelajaran dan menganggap adalah $1 \%$; siswa yang ragu-ragu terhadap kemenarikan dan kemudahan media pembelajaran adalah 6,37\%; siswa yang menyatakan setuju bahwa media ini menarik dan mempermudah pembelajaran adalah 52\% sedangkan siswa yang sangat setuju bahwa media pembelajaran ini menarik dan mempermudah pembelajaran adalah $40,62 \%$. Sedangkan pada uji coba 2 diperoleh data bahwa rata-rata persentase siswa sangat tidak setuju bahwa media ini menarik dan mempermudah pembelajaran adalah 0\%; siswa yang menganggap media tidak menarik dan tidak mempermudah pembelajaran adalah $0,3 \%$; siswa yang ragu-ragu terhadap kemenarikan dan kemudahan media pembelajaran adalah 3,5\%; siswa yang menyatakan setuju bahwa media ini menarik dan mempermudah pembelajaran adalah 53\% sedangkan siswa yang sangat setuju bahwa media pembelajaran ini menarik dan mempermudah pembelajaran adalah $41,3 \%$.

Dari hasil lembar respons siswa terhadap media pembelajaran diketahui bahwa persentase siswa yang tertarik dan merasa dipermudah dalam pembelajarannya lebih tinggi dibanding siswa yang tidak tertarik dan merasa tidak dipermudah dalam proses pembelajaran sehingga respons siswa terhadap media pembelajaran ini baik. Data lain yang nampak pada lembar respons siswa adalah pada uji coba 2 persentase siswa yang menganggap media pembelajaran ini menarik dan mempermudah pembelajaran naik, dari 52\% pada uji coba 1 menjadi $53 \%$ pada uji coba 2. Sedangkan siswa yang menganggap bahwa media pembelajaran ini sangat menarik dan sangat mempermudah pembelajaran juga naik, dari 40,6\% pada uji coba 1 menjadi 41,3\% pada uji coba 2 .

\section{3) Deskripsi Aktivitas Guru dalam Pembelajaran Terpadu}

Aktivitas guru yang diamati adalah tindakan yang dilakukan guru dalam kelas. Sebenarnya aktivitas guru ini telah tercermin dalam keterlaksanaan RPP dalam pembelajaran namun hal ini diperjelas dengan adanya lembar pengamatan aktivitas guru tersendiri. Pada tabel 4.10 terlihat bahwa semua aktivitas yang harus dilakukan oleh guru pada pertemuan 1 maupun pertemuan 2 uji coba 1 muncul kecuali aktivitas yang tidak relevan.

Dengan demikian aktiviats guru pada pertemuan 1 uji coba 1 dinilai sangat baik begitu pula dengan aktivitas guru pada pertemuan 2 uji coba 1 . Hasil uji coba 2 menunjukkan bahwa pada uji coba 2 pertemuan 1 semua aktivitas yang relevan muncul begitu pula denga aktivitas yang tidak relevan sehingga aktivitas guru pada pertemuan 1 uji coba 2 dinilai baik. Pada pertemuan 2 uji coba 2 semua 
aktivitas relevan muncul sedangkan aktivitas yang tidak relevan tidak muncul. Dengan demikian aktivitas guru pada pertemuan 2 uji coba 2 dinilai sangat baik. Kesimpulan umum untuk aktivitas guru adalah sangat baik. Deskripsi aktivitas guru ditampilkan Tabel 10.

Tabel 10 Hasil Pengamatan Aktivitas Guru Uji Coba 1 dan 2 Pertemuan 1 dan 2

\begin{tabular}{|c|c|c|c|c|c|}
\hline \multirow{2}{*}{ No } & \multirow{2}{*}{ Aktivitas Guru } & \multicolumn{2}{|c|}{ Uji 1} & \multicolumn{2}{|c|}{ Uji 2} \\
\hline & & $\mathbf{P 1}$ & $\mathbf{P 2}$ & P1 & $\mathbf{P 2}$ \\
\hline \multicolumn{6}{|c|}{ PERTEMUAN I } \\
\hline 1 & $\begin{array}{l}\text { Memberikan penjelasan umum tentang materi pembelajaran dan } \\
\text { kegiatan yang akan dilakukan dalam kelompok }\end{array}$ & 1 & 1 & 1 & 1 \\
\hline 2 & $\begin{array}{l}\text { Mendorong siswa mengemukakan pendapatnya / mengajukan } \\
\text { pertanyaan tentang materi / aktivitas yang akan dilakukan }\end{array}$ & 1 & 1 & 1 & 1 \\
\hline 3 & Membentuk kelompok & 1 & 1 & 1 & 1 \\
\hline 4 & Mendorong siswa untuk aktif terlibat dalam diskusi kelompok & 1 & 1 & 1 & 1 \\
\hline 5 & Membagikan LKS pembelajaran terpadu kepada siswa dalam kelompok & 1 & 1 & 1 & 1 \\
\hline 6 & $\begin{array}{l}\text { Mengarahkan dan memberi bantuan bila diperlukan dalam diskusi } \\
\text { kelompok }\end{array}$ & 1 & 1 & 1 & 1 \\
\hline 7 & $\begin{array}{l}\text { Memanggil perwakilan kelompok untuk mempresentasikan hasil kerja } \\
\text { kelompoknya di depan kelas, }\end{array}$ & 1 & 1 & 1 & 1 \\
\hline 8 & Mengarahkan siswa untuk memperhatikan presentasi kelompok lain & 1 & 1 & 1 & 1 \\
\hline 9 & Mengarahkan tanya jawab antara siswa dan guru & 1 & 1 & 1 & 1 \\
\hline 10 & Mengarahkan tanya jawab antara sesama siswa & 1 & 1 & 1 & 1 \\
\hline 11 & Merangkum materi pembelajaran & 1 & 1 & 1 & 1 \\
\hline 12 & Memberikan beberapa pertanyaan kepada siswa secara lisan & 1 & 1 & 1 & 1 \\
\hline \multicolumn{2}{|c|}{ Jumlah Aktivitas yang Relevan } & 12 & 12 & 12 & 12 \\
\hline \multicolumn{2}{|c|}{ Aktivitas Tidak Relevan } & $\mathbf{0}$ & $\mathbf{0}$ & 1 & 1 \\
\hline \multicolumn{2}{|c|}{ Jumlah Aktivitas seluruhnya } & 12 & 12 & 13 & 13 \\
\hline \multicolumn{6}{|c|}{ PERTEMUAN II } \\
\hline 1 & $\begin{array}{l}\text { Mengingatkan kembali siswa pada materi pelajaran pertemuan } \\
\text { sebelumnya. }\end{array}$ & 1 & 1 & 1 & 1 \\
\hline 2 & $\begin{array}{l}\text { Menyampaikan tujuan pembelajaran, melakukan undian giliran } \\
\text { tampilan kelompok. }\end{array}$ & 1 & 1 & 1 & 1 \\
\hline 3 & Membantu siswa bermain "Dor-Doran". & 1 & 1 & 1 & 1 \\
\hline 4 & $\begin{array}{l}\text { Memberikan kesempatan perwakilan kelompok untuk membacakan } \\
\text { hasil identifikasinya. }\end{array}$ & 1 & 1 & 1 & 1 \\
\hline 5 & Memberi kesempatan siswa lain mengomentari hasil kerja kelompok. & 1 & 1 & 1 & 1 \\
\hline 6 & Mengevalusai hasil kerja kelompok. & 1 & 1 & 1 & 1 \\
\hline \multicolumn{2}{|c|}{ Jumlah Aktivitas yang Relevan } & 6 & 6 & 6 & 6 \\
\hline \multicolumn{2}{|c|}{ Aktivitas tidak Relevan } & $\mathbf{0}$ & $\mathbf{0}$ & $\mathbf{0}$ & $\mathbf{0}$ \\
\hline \multicolumn{2}{|c|}{ Jumlah Aktivitas Seluruhnya } & 6 & 6 & 6 & 6 \\
\hline
\end{tabular}

Keterangan: 1 jika aktivitas muncul $\quad 0$ jika aktivitas tidak muncul

\section{a) Pertemuan 1 Uji Coba 1 dan 2}

Aktivitas pertama yang diamati adalah memberikan penjelasan umum tentang materi pembelajaran dan kegiatan yang akan dilakukan dalam kelompok. Penjelasan ini berlansung agak lama sekitar 10 menit sebab banyak pertanyaan yang dilontarkan oleh siswa seputar kegiatan yang akan dilakukan. Aktivitas kedua yang diamati adalah mendorong siswa untuk mengemukakan pendapatnya atau mengajukan pertanyaan tentang materi atau aktivitas yang akan dilakukan. Guru melakukan aktivitas ini dengan sesekali mananyakan pada siswa apakah ada pertanyaan terkait dengan materi atau aktivitas yang akan dilakukan. Guru melontarkan pertanyaan tersebut setiap selesai menyampaikan 1 atau 2 informasi kepada siswa sehingga jumlah menit yang digunakan guru sulit terukur. Aktivitas 
ketiga yang diamati adalah membentuk kelompok. Pada uji coba pembentukan kelompok hanya berlangsung selama 3 menit sedangkan pada uji coba 2 guru menghabiskan waktu selama 10 menit untuk membentuk kelompok. Hal ini disebabkan jumlah siswa cukup banyak (30 orang) dan guru kurang menguasai kelas.

Aktivitas keempat yang diamati adalah guru mendorong siswa untuk aktif terlibat dalam diskusi kelompok. Guru melakukan hal ini dengan berkeliling dari satu kelompok ke kelompok yang lain. Ada beberapa anak yang diingatkan guru untuk ikut diskusi. Anak-anak yang diingatkan tersebut adalah anak yang berperilaku ekstrim. Terlalu aktif atau terlalu pendiam. Anak yang terlalu aktif cenderung menunjukkan sikap superior kepada teman-temannya dan tidak mau mengalah kepada teman sehingga jika pendapatnya tidak diterima, mereka cenderung mengacau. Sedangkan anak yang terlalu pendiam, pasif tidak mau bergabung dengan kelompok dan pasrah pada hasil kerja temannya. Aktivitas selanjutnya adalah membagikan LKS pembelajaran terpadu kepada siswa dalam kelompok. Waktu yang digunakan guru untuk membagikan LKS ini kurang lebih adalah 5 menit. Mengarahkan dan memberi bantuan bila diperlukan dalam diskusi kelompok. Hal ini dilakukan guru sambil berkeliling. Jika ada pertanyaan dari siswa pada kelompok bersangkutan, guru melakukannya jika tidak guru hanya mengawasi jalannya diskusi. Aktivitas ketujuh adalah memanggil perwakilan kelompok untuk mempresentasikan hasil kerja kelompoknya di kelas. Guru memanggil perwakilan kelompok saat permainan tebak kata dilakukan oleh kelompok.

Aktivitas kedelapan adalah mengarahkan siswa untuk memperhatikan presentasi kelompok lain, guru melakukan hal ini dengan memberikan peringatan pada siswa yang nampak tidak mau terlibat dalam permainan tebak kata antar kelompok atau berbicara sendiri dengan teman 1 kelompoknya. Aktivitas ke sembilan adalah mengarahkan tanya jawab antar guru dan siswa. Guru melakukan aktivitas ini dengan cara menegaskan pertanyaan siswa yang kurang dapat dipahami maksudnya. Aktivitas selanjutnya adalah mengarahkan tanya jawab sesama siswa. ini dilakukan guru pada saat siswa berdiskusi secara berkelompok untuk membuat petunjuk tebakan. Aktivitas ke sebelas adalah merangkum materi pembelajaran. Guru merangkum materi pembelajaran pada kegiatan akhir dengan memberikan simpulan pembelajaran. Hal ini kira-kira berlangsung selama lima menit. Aktivitas terakhir yang diamati pada pertemuan 1 adalah memberikan pertanyaan kepada beberapa orang siswa secara lisan. Ini dilakukan oleh guru baik pada kegiatan awal, inti maupun akhir sehingga sulit terdeteksi berapa waktu yang digunakan oleh guru untuk melakukan kegiatan ini. Aktivitas tidak relevan yang muncul pada pertemuan 1 uji coba 2 adalah guru meninggalkan kelas karena terbatuk-batuk sehingga pembelajaran berhenti untuk beberapa saat.

\section{b) Pertemuan 2 uji coba 1 dan 2}

Pada pertemuan 2 baik pada uji coba 1 maupun uji coba 2,guru mengingatkan kembali siswa pada materi pelajaran pertemuan sebelumnya. Setelah itu guru menyampaikan tujuan pembelajaran dan melakukan undian giliran tampilan berkelompok. Hal ini dapat dilihat pada penjelasan keterlaksanaan RPP. Guru membantu siswa bermain "Dor-Doran" dengan cara menjadi juri dan petugas penempel kartu huruf. Selanjutnya guru memanggil 
perwakilan kelompok untuk membacakan hasil identifikasinya tentang lingkungan alam dan buatan, lingkungan sehat dan tidak sehat, penyebab dan cara memeliharanya, serta memberi kesempatan kepada beberapa siswa untuk menampilkan pekerjaannya tentang membuat petunjuk memelihara lingkungan dengan bergotong royong dan memberikan kesempatan siswa lain untuk mengomentari hasil kerja kelompok. Serta mengevaluasi hasil kerja kelompok dengan memberikan komentar dan saran perbaikan.

\section{4) Deskripsi Aktivitas Siswa dalam Pembelajaran Terpadu}

Aktivitas siswa yang diperhatikan adalah persentase keterlibatan siswa selama pembelajaran berlangsung yang diukur dengan lembar pengamatan aktivitas siswa. Aktivitas yang nampak mencakup: (1) memperhatikan penjelasan guru tentang materi pelajaran dan kegiatan yang akan dilakukan; (2) mengemukakan pendapat atau mengajukan pertanyaan kepada guru; (3) bergabung dalam kelompok belajar; (4) aktif terlibat dalam diskusi kelompok; (5) mengerjakan LKS tentang mengenal dan peduli lingkungan; (6) membantu teman dalam kelompoknya yang mengalami kesulitan; (7) meminta bantuan kepada teman dalam kelompoknya bila mengalami kesulitan; (8) mempresentasikan hasil kerja kelompoknya di depan kelas; (9) memperhatikan presentasi kelompok lain; (10) tanya jawab antara siswa dan guru; (11) tanya jawab antara siswa dan siswa; (12) merangkum materi pembelajaran; (13) menjawab pertanyaan yang diberikan oleh guru secara lisan; dan (14) aktivitas yang tidak relevan. Hasil pengamatan aktivitas siswa pada uji coba satu pertemuan 1 dan 2 dapat dilihat pada Tabel 11 .

Tabel 11 Aktivitas Siswa pada Ujicoba 1 dan 2

\begin{tabular}{|c|c|c|c|c|c|c|c|}
\hline \multirow{3}{*}{ No } & \multirow{3}{*}{ Aspek yang diamati } & \multicolumn{6}{|c|}{ Persentase Aktivitas Siswa per Pertemuan } \\
\hline & & \multicolumn{3}{|c|}{ Ujicoba 1} & \multicolumn{3}{|c|}{ Ujicoba 2} \\
\hline & & Pert. 1 & Pert. 2 & Rerata & Pert. 1 & Pert. 2 & Rerata \\
\hline 1. & $\begin{array}{l}\text { Memperhatikan penjelasan guru tentang } \\
\text { materi pelajaran dan kegiatan yang akan } \\
\text { dilakukan }\end{array}$ & 9,82 & 9,65 & 9,76 & 9,81 & 9,38 & 9,59 \\
\hline 2. & 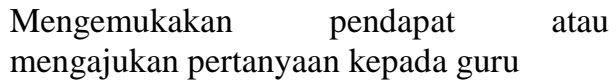 & 7,69 & 7,29 & 7,51 & 7,68 & 7,20 & 7,44 \\
\hline 3. & Bergabung dalam kelompok belajar & 8,52 & 8,47 & 8,52 & 8,51 & 8,23 & 8,37 \\
\hline 4. & Aktif terlibat dalam diskusi kelompok & 9,47 & 8,71 & 9,11 & 9,46 & 8,50 & 8,98 \\
\hline 5. & $\begin{array}{l}\text { Mengerjakan LKS tentang mengenal dan } \\
\text { peduli lingkungan }\end{array}$ & 9,47 & 9,41 & 9,47 & 9,46 & 9,15 & 9,31 \\
\hline 6. & $\begin{array}{l}\text { Membantu teman dalam kelompoknya } \\
\text { yang mengalami kesulitan }\end{array}$ & 9,23 & 9,18 & 9,23 & 9,22 & 8,92 & 9,07 \\
\hline 7. & $\begin{array}{l}\text { Meminta bantuan kepada teman dalam } \\
\text { kelompoknya bila mengalami kesulitan }\end{array}$ & 5,09 & 5,29 & 5,21 & 5,08 & 5,22 & 5,15 \\
\hline 8 & $\begin{array}{lll}\text { Mempresentasikan } & \text { hasil } & \text { kerja } \\
\text { kelompoknya di depan kelas } & \end{array}$ & 3,79 & 4,82 & 4,32 & 3,78 & 4,76 & 4,27 \\
\hline 9 & Memperhatikan presentasi kelompok lain & 9,23 & 9,06 & 9,17 & 9,22 & 8,80 & 9,01 \\
\hline 10 & Tanya jawab antara siswa dan guru & 8,88 & 9,29 & 9,11 & 8,87 & 9,03 & 8,95 \\
\hline 11 & Tanya jawab antara siswa dan siswa & 6,15 & 6,12 & 6,15 & 6,15 & 5,98 & 6,07 \\
\hline 12 & Merangkum materi pembelajaran & 4,73 & 4,71 & 4,73 & 4,73 & 6,68 & 5,71 \\
\hline 13 & $\begin{array}{l}\text { Menjawab pertanyaan yang diberikan oleh } \\
\text { guru secara lisan }\end{array}$ & 7,22 & 7,41 & 7,34 & 7,21 & 7,32 & 7,27 \\
\hline & Persentase Aktivitas Relevan & 99,29 & 99,41 & 99,35 & 99,17 & 99,35 & 99,26 \\
\hline & Aktivitas yang tidak relevan & 0,71 & $\mathbf{0 , 5 9}$ & 0,65 & $\mathbf{0 , 8 3}$ & 0,65 & 0,74 \\
\hline & Reliabilitas & 0,98 & 0,99 & 0,98 & 0,98 & 0,99 & 0,98 \\
\hline
\end{tabular}


Keterangan:

1. Sangat baik jika aktivitas relevan mencapai lebih dari $90 \%$

2. Baik jika aktivitas relevan berkisar antara $75-90 \%$

3. Kurang baik jika aktivitas relevan berkisar antara 50-75\%

4. Tidak baik jika aktivitas relevan kurang dari 50\%

Berdasarkan Tabel 11 diketahui bahwa rata-rata jumlah aktivitas yang relevan jauh lebih tinggi dibanding aktivitas yang tidak relevan. Pada uji coba 1 pertemuan 1 dan 2, rata-rata aktivitas siswa yang relevan dengan pembelajaran adalah 99,35 sedangkan aktivitas yang tidak relevan adalah 0,65. Pada uji coba 2 petemuan 1 dan 2, rata-rata aktivitas siswa yang relevan mencapai 99,26 sedangkan aktivitas yang tidak relevan adalah 0,74. Dengan demikian dapat disimpulkan bahwa siswa kelas III SDN 4 Balerejo mengikuti pembelajaran terpadu dengan media permainan tebak kata tradisional "Dor-Doran" secara serius dan aktivitas siswa dinilai sangat baik.

Rata-rata persentase aktivitas tertinggi yang muncul pada pembelajaran adalah memperhatikan penjelasan guru tentang materi pelajaran dan kegiatan yang akan dilakukan. Hal ini terjadi karena kegiatan yang akan dilakukan adalah kegiatan yang sifatnya baru bagi siswa. namun secara keseluruhan aktivitas siswa yang muncul cukup berimbang. Memang hal ini yang diharapkan dalam pembelajaran sebab seluruh aktivitas yang relevan saling terkait dan tidak dapat dipisahkan sebagai satu kesatuan. Nilai rata-rata koefisien reliabilitas lembar pengamatan aktivitas siswa baik pada uji coba 1 maupun uji coba 2 adalah 0,98 , lebih tinggi dari koefisien reliabilitas patokan, oleh karena itu lembar pengamatan aktivitas siswa dalam penelitian ini reliabel.

\section{5) Deskripsi Hasil Belajar Siswa dalam Pembelajaran}

Tes hasil belajar diberikan setelah selesai pembelajaran. Adapun tujuan pemberian tes ini adalah untuk mengukur kemampuan siswa dalam menguasai materi pelajaran yang telah diajarkan, sekaligus sebagai sarana memberikan umpan balik kepada siswa. Tes hasil belajar dibuat berdasarkan kisi-kisi THB yang disesuaikan dengan tujuan pembelajaran yang hendak dicapai pada pembelajaran terpadu dengan tema mengenal dan peduli lingkungan. Hasil belajar siswa serta ketuntasan individual siswa pada uji coba 1 ditampilkan Tabel 12.

Tabel 12 Hasil Belajar Siswa

\begin{tabular}{|c|c|c|c|c|c|c|}
\hline \multirow{2}{*}{ No } & \multirow{2}{*}{ Kode Siswa } & \multicolumn{2}{|c|}{ Skor } & \multirow{2}{*}{$\begin{array}{l}\text { Skor } \\
\text { Max. }\end{array}$} & \multirow{2}{*}{$\begin{array}{c}\text { Persentase } \\
\text { PHB }\end{array}$} & \multirow{2}{*}{$\begin{array}{c}\text { Ketuntasan } \\
\text { Individual }\end{array}$} \\
\hline & & Pretest & Postest & & & \\
\hline 1 & $\mathrm{~A}$ & 61 & 89 & 100 & 28 & $\mathrm{~T}$ \\
\hline 2 & B & 54 & 78 & 100 & 24 & $\mathrm{~T}$ \\
\hline 3 & $\mathrm{C}$ & 53 & 79 & 100 & 26 & $\mathrm{~T}$ \\
\hline 4 & $\mathrm{D}$ & 54 & 74 & 100 & 20 & $\mathrm{~T}$ \\
\hline 5 & $\mathrm{E}$ & 49 & 73 & 100 & 24 & $\mathrm{~T}$ \\
\hline 6 & F & 44 & 66 & 100 & 22 & $\mathrm{~T}$ \\
\hline 7 & $\mathrm{G}$ & 48 & 67 & 100 & 19 & $\mathrm{~T}$ \\
\hline 8 & $\mathrm{H}$ & 43 & 68 & 100 & 25 & $\mathrm{~T}$ \\
\hline 9 & I & 38 & 66 & 100 & 28 & $\mathrm{~T}$ \\
\hline 10 & $\mathrm{~J}$ & 43 & 68 & 100 & 25 & $\mathrm{~T}$ \\
\hline \multicolumn{2}{|c|}{ Rata-rata } & 48,7 & 72,8 & 100 & 24 & \\
\hline
\end{tabular}


Berdasarkan Tabel 12 diketahui bahwa dari sepuluh orang siswa yang mengikuti pembelajaran terpadu dengan media permainan tebak kata tradisional "Dor-Doran" semuanya mengalami kenaikan skor. Sedangkan persentase tertinggi yang diraih pada post test adalah 89 dan yang terendah adalah 66. Dengan demikian kesepuluh orang siswa tersebut dinyatakan tuntas belajarnya sebab standar KKM yang ditetapkan adalah 65. Ketuntasan kelas dihitung dengan cara membagi jumlah siswa yang tuntas dengan jumlah seluruh siswa, hasil pembagian tersebut selanjutnya dikalikan dengan 100\%. Sehingga diketahui ketuntasan belajar secara klasikal. Pada uji coba 1 ketuntasan belajar siswa adalah $100 \%$. Sedangkan rata-rata peningkatan hasil belajar adalah $24 \%$. Hasil belajar siswa SDN Balerejo 4 pada uji coba 2 atau uji luas tersaji dalam Tabel 13.

Tabel 13 Hasil Belajar Siswa Kelas 3 SDN 4 Balerejo dalam Pembelajaran Terpadu

\begin{tabular}{|c|c|c|c|c|c|c|c|c|c|c|c|c|c|}
\hline \multirow{2}{*}{ No } & \multirow{2}{*}{$\begin{array}{l}\text { Kode } \\
\text { Siswa }\end{array}$} & \multicolumn{2}{|c|}{ Skor } & \multirow{2}{*}{$\begin{array}{l}\text { Skor } \\
\text { Max }\end{array}$} & \multirow{2}{*}{$\begin{array}{c}\% \\
\text { PHB }\end{array}$} & \multirow{2}{*}{$\begin{array}{c}\text { Ketuntasan } \\
\text { Individual }\end{array}$} & \multirow{2}{*}{ No } & \multirow{2}{*}{$\begin{array}{l}\text { Kode } \\
\text { Siswa }\end{array}$} & \multicolumn{2}{|c|}{ Skor } & \multirow{2}{*}{$\begin{array}{l}\text { Skor } \\
\text { Max }\end{array}$} & \multirow{2}{*}{$\begin{array}{c}\% \\
\text { PHB }\end{array}$} & \multirow{2}{*}{$\begin{array}{l}\text { Ketuntasan } \\
\text { Individual }\end{array}$} \\
\hline & & Pretest & Postest & & & & & & Pretest & Postest & & & \\
\hline 1 & A & 61 & 92 & 100 & $31 \%$ & Tuntas & 16 & $\mathrm{P}$ & 40 & 63 & 100 & $23 \%$ & T. Tuntas \\
\hline 2 & B & 60 & 88 & 100 & $28 \%$ & Tuntas & 17 & $\mathrm{Q}$ & 47 & 68 & 100 & $21 \%$ & Tuntas \\
\hline 3 & C & 56 & 80 & 100 & $24 \%$ & Tuntas & 18 & $\mathrm{R}$ & 43 & 71 & 100 & $28 \%$ & Tuntas \\
\hline 4 & D & 53 & 74 & 100 & $21 \%$ & Tuntas & 19 & $\mathrm{~S}$ & 42 & 71 & 100 & $29 \%$ & Tuntas \\
\hline 5 & E & 49 & 76 & 100 & $27 \%$ & Tuntas & 20 & $\mathrm{~T}$ & 45 & 70 & 100 & $25 \%$ & Tuntas \\
\hline 6 & F & 47 & 71 & 100 & $24 \%$ & Tuntas & 21 & $\mathrm{U}$ & 61 & 89 & 100 & $28 \%$ & Tuntas \\
\hline 7 & $\mathrm{G}$ & 46 & 70 & 100 & $24 \%$ & Tuntas & 22 & V & 56 & 80 & 100 & $24 \%$ & Tuntas \\
\hline 8 & $\mathrm{H}$ & 49 & 70 & 100 & $21 \%$ & Tuntas & 23 & W & 53 & 80 & 100 & $27 \%$ & Tuntas \\
\hline 9 & I & 38 & 68 & 100 & $30 \%$ & Tuntas & 24 & $X$ & 54 & 74 & 100 & $20 \%$ & Tuntas \\
\hline 10 & $\mathrm{~J}$ & 43 & 68 & 100 & $25 \%$ & Tuntas & 25 & Y & 49 & 75 & 100 & $26 \%$ & Tuntas \\
\hline 11 & K & 62 & 91 & 100 & $29 \%$ & Tuntas & 26 & $\mathrm{Z}$ & 43 & 65 & 100 & $22 \%$ & T. Tuntas \\
\hline 12 & $\mathrm{~L}$ & 52 & 78 & 100 & $26 \%$ & Tuntas & 27 & AA & 49 & 71 & 100 & $22 \%$ & Tuntas \\
\hline 13 & $\mathrm{M}$ & 53 & 79 & 100 & $26 \%$ & Tuntas & 28 & $\mathrm{AB}$ & 44 & 69 & 100 & $25 \%$ & Tuntas \\
\hline 14 & $\mathrm{~N}$ & 54 & 72 & 100 & $18 \%$ & Tuntas & 29 & $\mathrm{AC}$ & 42 & 70 & 100 & $28 \%$ & Tuntas \\
\hline 15 & $\mathrm{O}$ & 52 & 77 & 100 & $25 \%$ & Tuntas & 30 & $\mathrm{AD}$ & 44 & 69 & 100 & $25 \%$ & Tuntas \\
\hline \multicolumn{8}{|c|}{ Rata-rata } & 49,56 & 74,63 & 100 & $25 \%$ & & \\
\hline
\end{tabular}

Berdasarkan Tabel 13 diketahui bahwa dari tiga puluh orang siswa yang mengikuti pembelajaran terpadu dengan permainan tebak kata tradisional "DorDoran" semuanya mengalami kenaikan skor. Sedangkan persentase tertinggi yang diraih pada post test adalah 92 dan yang terendah adalah 63. Ada 2 orang siswa yang tidak tuntas dalam pembelajaran yaitu siswa dengan kode $\mathrm{P}$ yang mencapai 63 saja dan siswa dengan kode $\mathrm{Z}$ yang mencapai 65. Namun demikian analisis PHB keduanya mengalami kenaikan yang cukup signifikan yaitu sebesar $22 \%$ dan $23 \%$, tidak jauh dari PHB rata-rata sebesar 25\%. Ketuntasan kelas dihitung dengan cara membagi jumlah siswa yang tuntas dengan jumlah seluruh siswa, hasil pembagian tersebut selanjutnya dikalikan dengan 100\%. Sehingga diketahui ketuntasan belajar secara klasikal. Pada uji coba 2 ketuntasan belajar klasikal siswa mencapai 93\%. Maka secara klasikal pembelajaran dinyatakan tuntas sebab nilai ketuntasan klasikal yang ditetapkan adalah $65 \%$.

6) Deskripsi Faktor Penghambat dan Faktor Pendukung yang Ditemukan pada Pembelajaran Terpadu

Beberapa faktor penghambat yang ditemukan pada uji coba satu dan uji coba 2 pertemuan satu dan dua yang paling menonjol adalah: (1) latar belakang lingkungan asal siswa beragam, ada yang berasal dari kota madiun bagian barat, ada pula yang berasal dari kota madiun bagian timur. Untuk siswa yang berasal dari kota Madiun bagian barat permainan "Dor-Doran" sudah tidak asing lagi tapi 
bagi siswa yang berasal dari kota Madiun bagian timur ternyata tidak mengenal permainan ini. Oleh karena itu guru harus memperkenalkan secara umum bentuk permainan ini; dan (2) guru kurang menguasai kelas pada uji coba luas sebab siswa kelas III ternyata sangat aktif sehingga kadang-kadang menyusahkan. Ketika ada perlombaan permainan antar kelompok, siswa tiba-tiba mencetuskan jawaban sebelum ditunjuk sehingga guru kesulitan mengidentifikasi siswa mana yang menjawab. Hal ini diantisipasi guru dengan menerapkan aturan staples mulut. Gambaran aturan tersebut adalah jika siswa menjawab sebelum ditunjuk, maka dia dan kelompoknya didiskualifikasi untuk sementara dengan meletakkan tangan di depan mulut (mengunci mulut) sampai ada siswa lain yang melanggar.

Selain faktor penghambat pembelajaran ada beberapa faktor yang mendukung pembelajaran. Adapun faktor pendukung pembelajaran yang ditemukan pada pertemuan 1 dan 2 uji coba 1 antara lain adalah: (1) sebagian besar siswa, mempunyai pengalaman bermain dengan alat permainan dan jarang bermain bersama dengan teman sehingga kegiatan belajar ini menjadi sesuatu yang sangat menarik bagi siswa; dan (2) sikap ingin tahu siswa sangat besar ditunjukkan dengan keaktifan mereka dalam bertanya dan berebut menjawab membuat suasana belajar menjadi dinamis hanya saja memang dituntut penguasaan kelas yang baik oleh guru, agar hal ini tidak menjadi bumerang bagi pembelajaran.

\section{Pembahasan}

Penelitian yang telah dilakukan bertujuan untuk mendeskripsikan pengembangan perangkat pembelajaran terpadu berbasis potensi lokal di kabupaten Madiun. Adapun salah satu potensi yang diangkat adalah, permainan tebak kata tradisional "Dor-Doran". Tujuan kedua adalah untuk mendeskripsikan kualitas perangkat pembelajaran terpadu yang dihasilkan.

a. Pengembangan Perangkat Pembelajaran Terpadu

Pengembangan perangkat pembelajaran terpadu berbasis potensi lokal diawali dengan observasi awal untuk mengidentifikasi tujuan pembelajaran yang ingin dicapai. Selanjutnya dilakukan analisis pembelajaran, analisis karakteristik siswa, perumusan tujuan pembelajaran, penyusunan tes pembelajaran terpadu, mengembangkan RPP dan media, pengembangan buku pegangan guru, buku pegangan siswa, dan LKS pembelajaran terpadu dengan media permainan tebak kata tradisional "Dor-Doran". Hal ini sesuai dengan Model perancangan dan pengembangan pengajaran Dick and carey (1991:2) Perangkat yang dihasilkan disebut sebagai draft 1 . Selanjutnya dilakukan validasi terhadap draft 1 . Validasi dilakukan oleh dua orang pakar untuk melihat validitas isi dan konstruk perangkat yang telah dilakukan.

Selanjutnya perangkat kembali direvisi sesuai dengan masukan dari ahli dan disebut sebagai draft 2. Draft 2 diuji coba terbatas pada sepuluh orang siswa dari kelas III SDN Balerejo 2 Kabupaten Madiun untuk melihat keterlaksanaan perangkat yang telah dihasilkan. Selanjutnya dari uji coba 1 dilakukan analisis terhadap perangkat pembelajaran yang telah dihasilkan sehingga diketahui persentase keterlaksanaan perangkat. Nilai persentase ini selanjutnya dideskripsikan untuk digunakan sebagai masukan pada perangkat draft dua sehingga perangkat menjadi lebih sempurna untuk diujikan pada uji luas yang dilakukan di kelas 3 SDN 4 Balerejo Kabupaten Madiun. 


\section{b. Kualitas Perangkat Pembelajaran}

Kualitas perangkat pembelajaran ditinjau dari validitas perangkat, yaitu validasi RPP, validasi media, validasi BPG, BAS, validasi LKS, dan validasi THB. Perangkat pembelajaran yang telah dikembangkan kemudian divalidasi oleh 2 orang pakar/ahli. Sebagaimana dikemukakan Reigeluth (dalam Prawiradilaga, 2008) bahwa pengembangan pembelajaran merupakan proses pelaksanaan di lapangan dari apa yang sudah diselesaikan dalam disain yang merupakan kisi-kisi (blueprint) yang masih harus divalidasikan ketepatannya. Berikut analisis deskriptif hasil validasi perangkat pembelajaran yang dihasilkan.

\section{1) Kualitas RPP}

Penilaian kelayakan RPP oleh validator ahli 1 menunjukkan skor penilaian rata-rata tiga kategori yaitu format, isi, dan bahasa sebesar 4,44 dengan kriteria baik. Sedangkan penilaian dari validator ahli 2 menunjukkan nilai rata-rata dari ketiga kategori 4 dengan kriteria baik. Dari skor kedua validator di rata-rata menjadi 4,22 sehingga dapat disimpulkan bahwa RPP yang dikembangkan mencapai kriteria yang baik. Sebagaimana dijelaskan dalam Permendiknas Nomor 41 tahun 2007 tentang Standar Proses untuk Satuan Pendidikan Dasar dan Menengah, bahwa setiap guru pada satuan pendidikan berkewajiban menyusun RPP secara lengkap dan sistematis agar pembelajaran berlangsung secara interaktif, inspiratif, menyenangkan, menantang, memotivasi peserta didik untuk berpartisipasi aktif, serta memberikan ruang yang cukup bagi prakarsa, kreativitas, dan kemandirian sesuai dengan bakat, minat, dan perkembangan fisik serta psikologis peserta didik. Hasil penilaian dengan kriteria baik pada setiap kategori menunjukkan bahwa komponen-komponen penyusun RPP telah terpenuhi dengan benar, sehingga dapat disimpulkan bahwa RPP yang dikembangkan sesuai dan layak digunakan sebagai perangkat pembelajaran.

\section{2) Kualitas Media}

Untuk validasi media, validator 1 memberikan penilaian sebesar 5 dengan kategori sangat baik, untuk 3 aspek yang dinilai meliputi kemudahan, kemenarikan, dan fleksibilitas. Sedangkan validator 2 memberikan nilai rata-rata 4 dengan kategori baik untuk 3 aspek yang dinilai. Jika dirata-rata penilaian kedua validator terhadap media yang dihasilkan adalah 4,5 dengan kriteria baik. Media ini menjadi menarik sebab selain mengangkat permainan tradisional yang hampir punah, juga sesuai dengan karakteristik anak sekolah dasar yag berada pada tahap operasional konkret dan senang bermain. Syarat fleksibilitas terpenuhi oleh media ini sebab media ini dapat mewadahi banyak tujuan pembelajaran bahkan banyak kompetensi dasar.

\section{3) Kualitas BPG}

Nilai rata-rata validasi BPG dari validator 1 adalah 4,29 dengan kriteria baik sedangkan validasi BPG dari validator 2 adalah 4 juga dengan kriteria baik. Jika dirata-rata hasil validasi keduanya menunjukkan nilai 4,14 dengan kriteria baik. Hal ini berarti BPG yang dihasilkan telah memenuhi syarat buku ajar yang baik. Sesuai dengan syarat yang diajukan oleh Pusat Perbukuan Diknas, buku yang baik harus memenuhi kriteria utama berupa materi, penyajian, dan kebahasaan. 


\section{4) Kualitas BAS}

Analisis hasil penilaian kelayakan BAS oleh Validator 1 menunjukkan rata-rata skor penilaian dari tiga kategori (format, isi dan bahasa) sebesar 4,45 dengan kriteria baik. Hasil penilaian Validator 2 menunjukkan rata-rata skor penilaian dari tiga kategori (format, isi dan bahasa) sebesar 4,08 dengan kriteria baik. Dari skor kedua validator di rata-rata menjadi 4,26, jadi dapat disimpulkan bahwa BAS yang dikembangkan mencapai kriteria yang baik. Pencapaian kriteria baik ini mengandung makna bahwa BAS yang dikembangkan memenuhi kelengkapan, keakuratan, serta kegiatan yang mendukung materi pada aspek isi terpenuhi. Tampilan umum, tata letak, pemilihan huruf, dan variasi dalam cara penyampaian materi dari aspek format terpenuhi. Kejelasan maksud kalimat dan kesesuaian bahasa yang digunakan juga terpenuhi. Hal ini sejalan dengan standar yang diajukan oleh BSNP tentang kriteria buku yang baik.

\section{5) Kualitas LKS}

Hasil validasi LKS menunjukkan bahwa penilaian dari validator 1 untuk rata-rata tiga kategori (format, bahasa, dan isi) menunjukkan hasil 4,18 dengan kategori baik. Sedangkan penilaian validator 2 menunjukkan hasil 3,75 dengan kategori baik pula. Jika dirata-rata, hasil dari kedua penilaian tersebut adalah 3,96. Dari hasil rata-rata nilai tersebut diketahui bahwa LKS yang dikembangkan bisa digunakan sebagai perangkat pembelajaran yang representatif. Oleh karena itu LKS yang dikembangkan dalam penelitian ini berisi tugas yang membimbing siswa pada penemuan konsep melalui diskusi kelompok dan pengamatan terhadap lingkungan sekitar. Adakalanya pengamatan wujud lingkungan sekitar itu diwakili dengan gambar yang ditampilkan dalam LKS.

\section{6) Kualitas Instrumen THB}

Instrumen Tes hasil belajar yang dikembangkan sebanyak 10 soal yang seluruhnya berbentuk soal uraian. Wahyudin (2006:110) menyatakan bahwa ada dua hal yang harus diperhatikan dalam menulis soal. Kisi-kisi soal harus mampu mengungkap indikator hasil belajar yang diukur. Selain itu soal harus mengikuti pedoman kaidah penulisan soal sehingga soal yang dihasilkan memiliki kualitas yang baik. Kaidah yang dimaksud dalam penulisan soal meliputi penggunaan bahasa yang baik, tidak mengutip langsung dari buku, dan tidak ditulis dalam bahasa lokal. Terkait dengan hal tersebut maka validitas yang diukur pada soal meliputi validitas isi dan kebahasaan serta kesimpulan dari keduanya. Hasil validasi dari validator 1 dan validator 2 menunjukkan bahwa tes hasil belajar yang dikembangkan valid, dapat dipahami, dan dapat digunakan dengan revisi kecil, sehingga dapat disimpulkan bahwa THB yang dikembangkan sesuai dan layak digunakan sebagai perangkat pembelajaran.

\section{c. Implementasi Perangkat Pembelajaran}

Penerapan perangkat pembelajaran dalam penelitian ini dilakukan masih dalam satu rangkaian tahap pengembangan perangkat pembelajaran, Tujuan penerapan adalah untuk mengetahui keterlaksanaan penggunaan perangkat pembelajaran dalam menunjang kegiatan pembelajaran. Batasan tentang efektivitas penerapan perangkat pembelajaran adalah ukuran keberhasilan 
penerapan suatu perangkat pembelajaran yang didasarkan pada aspek keterlaksanaan RPP pembelajaran terpadu dengan menggunakan media tebak kata tradisional "Dor-Doran dengan kategori baik, aktivitas siswa selama pembelajaran terpadu dengan menggunakan media tebak kata tradisional "Dor-Doran, respons siswa terhadap pembelajaran pembelajaran terpadu dengan menggunakan media tebak kata tradisional "Dor-Doran positif, hasil belajar siswa setelah mengikuti pembelajaran dapat mencapai kriteria ketuntasan minimal individu dan kelas sebesar 65\%, serta reliabilitas instrumen mencapai 75\%. Analisis deskriptif tentang keterlaksanaan penggunaan perangkat pembelajaran secara operasional dapat dilihat dari uraian beberapa indikator berikut.

\section{1) Keterlaksanaan RPP Terpadu}

Dari hasil perhitungan terhadap data kuantitatif diketahui bahwa rata-rata persentase keterlaksanaan RPP pertemuan 1 uji coba 1 dan 2 adalah 89,75\%. Sedangkan rata-rata persentase keterlaksanaan RPP pertemuan 2 uji coba 1 dan 2 adalah $91,01 \%$. Hal ini menunjukkan bahwa RPP yang dikembangkan dapat diaplikasikan dalam pembelajaran dengan baik. Lebih dari $50 \%$ komponen RPP terlaksana. Angka keterlaksanaan tersebut dihasilkan dari proses pengembangan dan diskusi intensif, dengan para validator sebelum penerapan dalam pembelajaran di kelas maupun dengan pengamat dan guru ketika penerapan di kelas. Reliabilitas instrumen baik pada uji coba 1 maupun uji coba 2 sangat tinggi. Hal ini ditunjukkan dengan koefisien reliabilitas yang dicapai pada masingmasing uji coba. Pada uji coba 1 koefisien reliabilitas yang tercapai adalah 0,96 sedangkan pada uji coba 2 tercapai koefisien reliabilitas yang sama.

2) Respons Siswa terhadap Penggunaan Perangkat Pembelajaran Terpadu.

Dalam rangka membangkitkan minat siswa. Penggunaan permainan tradisional pada pembelajaran adalah sesuatu yang sifatnya baru karena kebaruan tersebut maka pembelajaran ini akan menjadi menarik bagi siswa. Oleh karena itu yang diukur dari respons siswa terhadap pembelajaran ini adalah aspek kemenarikan dan kemudahan. Persentase siswa yang setuju dan sangat setuju bahwa pembelajaran terpadu dengan media permainan tebak kata tradisional "Dor-Doran" ini menarik dan mudah untuk diikuti jauh lebih tinggi dibanding siswa yang tidak setuju dan ragu-ragu. Hal ini dapat dilihat pada Tabel 10. dengan demikian dapat disimpulkan bahwa respons siswa terhadap pembelajaran ini sangat baik. Media yang digunakan juga menarik bagi siswa sehingga suasana kelas menjadi menyenangkan.

\section{3) Aktivitas Guru dalam Pembelajaran Terpadu.}

Semua aktivitas yang relevan dengan pembelajaran yang harus dilakukan oleh guru muncul. Aktivitas yang tidak relevan hanya muncul pada pertemuan 1 uji coba 2 karena kondisi guru tidak memungkinkan untuk melanjutkan pembelajaran. Guru keluar dari kelas selama beberapa waktu sebab terbatukbatuk. Dalam hal ini guru keluar kelas dengan tujuan untuk menunggu batuknya reda tanpa mempertimbangkan apakah waktu untuk pembelajaran akan berjalan efektif atau tidak sehingga aktivitas ini dianggap sebagai aktivitas yang tidak relevan. Jika diamati lebih lanjut, semua aktivitas relevan yang dilakukan oleh guru adalah aktivitas yang bersifat memancing, mengarahkan, dan membantu 
siswa untuk melakukan aktivitas dalam pembelajaran serta menemukan konsep secara mandiri. Hal ini berarti bahwa guru hanya berlaku sebagai fasilitator dalam pembelajaran sesuai dengan prinsip pembelajaran terpadu yang dikemukakan oleh Prabowo (2000:3) bahwa pembelajaran terpadu sebagai suatu proses mempunyai beberapa ciri diantaranya adalah student centered.

4) Aktivitas Siswa dalam Pembelajaran Terpadu dengan menggunakan Media Permainan Tebak Kata Tradisional "Dor-Doran"

Secara umum persentase keterlibatan siswa dalam pembelajaran terpadu dengan menggunakan media permainan tebak kata tradisional "Dor-Doran" sangat tinggi. Pada uji coba 1 pertemuan 1, persentase aktivitas yang relevan mencapai 99,29\% sedangkan aktivitas yang tidak relevan dengan pembelajaran adalah $0,71 \%$. Hasil uji coba 1 pertemuan 2 menunjukkan bahwa persentase aktivitas yang relevan dengan pembelajaran adalah $99,41 \%$ sedangkan yang tidak relevan adalah $0,65 \%$. Jika dirata-rata persentase aktivitas yang relevan pada pertemuan 1 adalah $99,35 \%$ sedangkan aktivitas yang tidak relevan adalah $0,65 \%$. Hasil yang dicapai pada uji coba 2 pertemuan 1 dan 2 tidak jauh dari uji coba 1 . Pada uji coba 2 pertemuan 1, persentase aktivitas yang relevan mencapai $99,17 \%$ sedangkan aktivitas yang tidak relevan dengan pembelajaran adalah $0,83 \%$.

Hasil uji coba 2 pertemuan 2 menunjukkan bahwa persentase aktivitas yang relevan dengan pembelajaran adalah 99,35\% sedangkan yang tidak relevan adalah $0,65 \%$. Jika dirata-rata persentase aktivitas yang relevan pada pertemuan 1 adalah $99,35 \%$ sedangkan aktivitas yang tidak relevan adalah $0,74 \%$. Tingginya persentase yang dicapai pada lembar pengamatan menunjukkan bahwa siswa terlibat dengan intens dalam proses pembelajaran. Hal ini mendukung pernyataan bahwa respons siswa terhadap pembelajaran sangat positif. Sesuai dengan pendapat Krathwohl dalam Zaim (2008) yang menyatakan bahwa tingkat responsding meupakan partispasi aktif peserta didik, yaitu sebagai bagian dari perilakunya. Pada tingkat responsding, peserta didik tidak hanya memperhatikan fenomena khusus tetapi dia juga bereaksi. Koefisien reliabilitas instrumen pada uji coba satu adalah $0,98 \%$ begitu juga pada uji coba 2 . Hal ini berarti lembar pengamatan aktivitas siswa ini sangat reloabel sebab koefisien reliabilitas yang dicapai jauh lebih tinggi dibandingkan koefisien reliabilitas patokan yang hanya bernilai 0,75 .

5) Hasil Belajar dalam Pembelajaran Terpadu dengan menggunakan Media Permainan Tebak Kata Tradisional "Dor-Doran"

Hasil belajar adalah salah satu indikator yang menunjukkan bahwa pembelajaran telah berjalan dengan baik. Dalam hal ini pembelajaran dikatakan berjalan dengan baik jika aspek penyajian oleh guru memenuhi kriteria baik, respons siswa terhadap pembelajaran baik, ada interaksi intelektual antara guru dengan siswa. Hal ini sejalan dengan Hasil belajar siswa yang dapat mencapai ketuntasan tidak terlepas dari terlaksananya rencana pelaksanaan pembelajaran dengan baik, siswa yang aktif selama kegiatan belajar mengajar dan respons positif siswa terhadap pembelajaran. Hal ini sejalan dengan pendapat Yager yang mengemukakan bahwa hasil belajar bukan semata-mata bergantung pada apa yang disajikan guru, melainkan dipengaruhi hasil interaksi antara berbagai informasi 
yang seharusnya diberikan kepada anak dan bagaimana anak mengolah informasi berdasarkan pemahaman yang telah dimiliki sebelumnya (Rohandi, 1998).

Sesuai data sepuluh orang siswa yang mengikuti pembelajaran terpadu dengan media permainan tebak kata tradisional "Dor-Doran" semua siswa mengalami kenaikan skor yang signifikan. Skor tertinggi yang diraih pada post tes adalah 89 sedangkan yang terendah adalah 66. Dengan demikian kesepuluh orang siswa yang mengikuti pembelajaran terpadu dengan media permainan tebak kata tradisional "Dor-Doran" ini dinyatakan tuntas sebab KKM yang harus dicapai siswa adalah 65. Oleh karena itu ketuntasan klasikal pada uji coba 1 adalah $100 \%$. Hal yang berbeda terjadi pada uji coba 2. Dari tabel 4.13 diketahui bahwa tiga puluh orang siswa yang mengikuti pembelajaran terpadu dengan media permainan tebak kata tradisional "Dor-Doran", semuanya mengalami kenaikan skor. Persentase tertinggi yang diraih pada post tes adalah 92 sedangkan yang terendah adalah 63. Dalam uji coba 2 ini ada 2 orang siswa yang tidak tuntas secara individual yaitu siswa dengan kode $\mathrm{P}$ dengan skor post test 63 dan siswa dengan kode $\mathrm{Z}$ dengan skor post tes 65. Namun demikian dari analisis PHB diketahui bahwa keduanya mengalami kenaikan hasil belajar yang signifikan yaitu 22\% untuk P dan 23\% untuk Z. Hal ini tidak jauh berbeda PHB rata-rata kelas sebesar 25\%. Ketuntasan klasikal mencapai $93 \%$ maka secara klasikal pembelajaran dikatakan tuntas sebab nilai ketuntasan klasikal yang ditetapkan adalah $65 \%$.

\section{6) Faktor Penghambat dan Pendukung Pada Pembelajaran Terpadu}

Dari deskripsi faktor penghambat pembelajaran diperoleh fakta: (1) latar belakang lingkungan asal siswa beragam, untuk siswa yang berasal dari kota Madiun bagian barat permainan "Dor-Doran" sudah tidak asing lagi tapi bagi siswa yang berasal dari kota Madiun bagian timur ternyata tidak mengenal permainan ini; dan (2) guru kurang menguasai kelas pada uji coba luas sebab siswa kelas III ternyata sangat aktif sehingga kadang-kadang menyusahkan ketika ada perlombaan permainan antar kelompok. siswa tiba-tiba mencetuskan jawaban sebelum ditunjuk sehingga guru kesulitan mengidentifikasi siswa mana yang menjawab. Hal ini diantisipasi guru dengan menerapkan aturan staples mulut.

Dari deskripsi faktor pendukung pembelajaran diperoleh fakta: (1) sebagian besar siswa, mempunyai pengalaman bermain dengan alat permainan dan jarang bermain bersama dengan teman sehingga kegiatan belajar ini menjadi sesuatu yang sangat menarik bagi siswa; dan (2) rasa ingin tahu siswa membuat suasana belajar menjadi dinamis hanya saja memang dituntut penguasaan kelas yang baik oleh guru.

\section{E. KESIMPULAN}

Simpulan dari temuan penelitian adalah secara umum proses pengembangan perangkat dalam penelitian pengembangan ini berjalan dengan baik. Kualitas hasil pengembangan juga baik terbukti dengan tingkat validitas masing-masing perangkat yang dihasilkan baik secara konstruk maupun secara isi baik. Kualitas media yang dihasilkan baik, memenuhi kriteria kemenarikan, kemudahan penggunaan, dan fleksibilitas. Implementasi perangkat pembelajaran yang dihasilkan baik, ditunjukkan dengan tingginya persentase keterlaksanaan pembelajaran. Untuk faktor penghambat yang terjadi dalam pembelajaran mampu diatasi dengan baik oleh guru dengan cara berimprovisasi. 


\section{DAFTAR RUJUKAN}

Collins, G., dan Dixon, H. 1991. Integrated Learning Planned Curriculum Units. Gosford: Bookshelf Publishing Australia.

Departemen Pendidikan dan Kebudayaan. 1980. Permainan Rakyat Daerah Jawa Timur. Proyek Inventarisasi dan Dokumentasi Kebudayaan Daerah Pusat Penelitian Sejarah dan Budaya. Jakarta: Depdikbud.

Departemen Pendidikan dan Kebudayaan. 1994. Kurikulum 1994. Jakarta: Depdikbud.

Dick, W., dan Carey, L. 1991. The Systematic Design of Instruction. Glenview: IL Scott Foresman.

Dimyati, dan Mudjiono. 2006. Belajar dan Pembelajaran. Jakarta: Rineka Cipta.

Fogarty, R. 1991. The Minful School How to Integrate the Curricula, Illionis: IRI/Skylight publishing, Inc.

Gerlach, Vernon, S., dan Ely, D. P. 1971. Theaching and Media. New Jersey: Prentice Hall Inc.

Ghafur, A. 2007. Bahan Diklat Profesi Guru Sertifikasi Guru Rayon II DIY Jateng. Yogyakarta: Pusat Pengembangan Rencana Pelaksanaan Pembelajaran.

Isnaini, D. M. 2009. Pengembangan Perangkat Model Pembelajaran OME-AKE untuk Pembelajaran Apresiasi Sastra di Kelas III Sekolah Dasar. Tesis tidak diterbitkan. Surabaya: Universitas Negeri Surabaya.

Nur, M. 2000. Strategi-Strategi Belajar. Surabaya: Universitas Negeri Surabaya.

Piaget, J. 1950. The Cild's Conception of Movement and Speed. London: Routledge and Kegan Paul.

Pusat Perbukuan 2003. Standar Komponen Buku Ajar. Jakarta: Pusat Perbukuan.

Rusijono, dan Yulianto, B. 2008. Assesmen Pembelajaran. Surabaya: Unesa.

Slavin, R. E. 1997. Educational Psychology: Theory and Practice. Massachusetts: Allyn and Bacon Publishers.

Sugiyono. 2007. Metode Penelitian Pendidikan Pendekatan Kuantitatif, Kualitatif, dan $R \& D$. Bandung: Alfabeta.

Tim PPKP. 2007. Pengembangan Inovasi Pembelajaran. Jakarta: Direktorat Ketenagaan Dirjen Dikti Depdiknas. 
Wahyudin, U. 2006. Evaluasi Pembelajaran SD. Bandung: UPI Press.

Zaim, E. 2008. Membumikan Pendidikan Nilai, Mengumpulkan yang Terserak, Menyambung yang Terputus dan Menyatukan yang Tercerai. Bandung: Alfabeta. 